\title{
COLLECTIVE MEMORY MEETS ORGANIZATIONAL IDENTITY: REMEMBERING TO FORGET IN A FIRM'S RHETORICAL HISTORY
}

\author{
MICHEL ANTEBY \\ Harvard University \\ VIRÁG MOLNÁR \\ New School for Social Research
}

\begin{abstract}
Much organizational identity research has grappled with the question of identity emergence or change. Yet the question of identity endurance is equally puzzling. Relying primarily on an analysis of 309 internal bulletins produced at a French aeronautics firm over almost 50 years, we theorize a link between collective memory and organizational identity endurance. More specifically, we show how forgetting in a firm's ongoing rhetorical history-here, the bulletins' repeated omission of contradictory elements in the firm's past (i.e., structural omission) or attempts to neutralize them with valued identity cues (i.e., preemptive neutralization)—sustains its identity. Thus, knowing "who we are" might depend in part on repeatedly remembering to forget "who we were not."
\end{abstract}

Since the foundational piece by Albert and Whetten (1985) in which they define organizational identities as the shared beliefs of members about the central, enduring, and distinct characteristics of their organization, much research has focused on the question of identity emergence or change; singular events or junctures that might impact identities have therefore proven sought-out loci of research. Many studies on organizational identities have focused, for instance, on initial formation stages (e.g., Corley \& Gioia, 2004), on mergers (e.g., Clark, Gioia, Ketchen, \& Thomas, 2010), on sudden regulatory changes (e.g., Fox-Wolfgramm, Boal, \& Hunt, 1998), or on other key disruptive events in the lives of organizations (e.g., Dutton \& Dukerich,

We are grateful to Michael Pratt and the three anonymous $A M J$ reviewers for their guidance on this article as well as to Elena Corsi, Marina Dal Soglio, Vincent Dessain, and Kathleen Ryan for their assistance in data collection. We also thank Julie Battilana, Frank Dobbin, Karen Golden-Biddle, Mary Ann Glynn, Jay Lorsch, Joshua Margolis, Chris Marquis, Tsedal Neeley, Nitin Nohria, Lakshmi Ramarajan, Mike Tushman, Amy Wrzesniewski, and Tieying Yu for their comments. The article has benefited from participants' feedback at the ASA Annual Meeting (Boston), the CNRS-sponsored "Labor and Organization” Colloquium (Aix-en-Provence), the May Meaning Meeting, McGill University, and Tsinghua University. Both authors contributed equally.

Editor's note: The manuscript for this article was accepted for publication during the term of $A M J$ 's previous editor-in-chief, R. Duane Ireland.
1994). These studies mostly center on the efforts needed for identities to be created or evolve.

Yet the question of identity endurance is perhaps as puzzling as that of identity emergence or change. The criterion for deeming an organization's defining characteristics as enduring is relative temporal continuity. A firm might, for instance, be said, over decades, to be "innovative" or "caring of its employees.” But how identities actually endure over extended periods of time remains empirically poorly understood. Besides a small number of studies (Ravasi \& Schultz, 2006; Tripsas, 2009), most organizational identity research focuses on discrete moments in time or events over limited time spans (i.e., several years). As Gioa et al. noted, identity endurance remains problematic, and more studies are needed to understand "how organizational members work to maintain continuity" (Gioia, Schultz, \& Corley, 2000: 76).

In this article, we analyze the endurance of a central dimension of an organization's identity over nearly 50 years by conducting an archival analysis of a French aeronautics firm's collective memory (Halbwachs, 1992; Olick, 2007; Olick \& Levy, 1997)—specifically, its ongoing "rhetorical history," or the process by which managers impose meaning on a firm's past (Foster, Suddaby, Minkus, \& Wiebe, 2011: 104). Using a theory elaboration approach (Strauss, 1987: 306-311), we document the interplay between organizational identity and collective memory by showing how repeated forgetting in a firm's rhetorical history helps sustain 
elements of the organization's identity over time. Repeated forgetting is manifested here in ongoing, deliberate omission of potentially contradictory aspects of an organization's history (i.e., what we label "structural omission") or the ongoing deliberate attempt to neutralize these contradictory aspects with valued identity cues (i.e., "preemptive neutralization").

In recent years, organizational identity and collective memory have, separately, become the subjects of intensive study. Their intersection, however, has been largely ignored. Our study aims to bridge these literatures by documenting how the ongoing historical construction of collective memory relates to an organization's identity. In particular, our study brings attention to a collective memory dimension (specifically, forgetting) present in organizational identity work. Moreover, we show that forgetting is as integral to collective memory as remembering. In that sense, the question "who we are" might be tightly linked to repeatedly remembering to forget "who we were not."

\section{THE NEGLECTED PUZZLE OF IDENTITY ENDURANCE}

Following Albert and Whetten's (1985) work, an increasing consensus has emerged among scholars that organizational identities need to be actively claimed (Glynn, 2000). This view probably explains why much organizational identity research has examined moments of organizational emergence or change when most of the claiming is assumed to occur (Corley et al., 2006: 93). In that respect, organizational identity formation moments have proven key areas of research (Clegg, Rhodes, \& Kornberger, 2007; Corley \& Gioia, 2004; Czarniawska \& Wolff, 1998; Gioia, Price, Hamilton, \& Thomas, 2010). In addition, singular events that disrupt established identities have been a common focus of organizational identity research (Brown, 2006; Corley \& Gioia, 2004; Dutton \& Dukerich, 1991; Elsbach \& Kramer, 1996; Fiol, 2002; FoxWolfgramm et al., 1998; Gioia et al., 2000; Gioia \& Thomas, 1996; Ravasi \& Schultz, 2006). Examples include a study of how the hiring of professional social workers by a rape crisis center formerly led by feminist militants changed its identity (Zilber, 2002) and a study of how the merger of two rival organizations allowed for a transitional identity to emerge (Gioia et al., 2010). These studies center on organization members' efforts to "enact" new identities (Weick, 1969) or to allow them to evolve at moments of transition.

At the same time, most organizational identity research takes somewhat for granted that identities endure by focusing on the efforts it takes to create or change them, not on what it takes for organizational identities to stay the same. Put otherwise, identity endurance is rarely seen as a puzzle to be explained; it is assumed as relatively unproblematic and remains empirically neglected. Yet staying the same requires efforts and work (Gagliardi, 1986: 124-125). As Whetten noted, "The enduring definition standard [of identities] does not stipulate that only very old organizational features will be experienced by current members as central and distinguishing features. Rather ... organizations are capable of signaling their intent to make recent commitments endure" (Whetten, 2006: 225). How organizations signal their intents over extended periods of time is still poorly understood.

An initial set of answers to the puzzle of identity endurance might come from the identity work literature. Endurance can be seen as an outcome of repeated "identity work" (Alvesson \& Willmott, 2002; Ashforth, Harrison, \& Corley, 2008; Ibarra, 1999; Pratt, Rockmann, \& Kaufmann, 2006; Snow \& Leon, 1987; Van Maanen, 1998; Watson, 2008). The more often an identity is (re)enacted, the more strongly stakeholders are likely to experience it, and the more enduring it might prove. Accordingly, previously explored identity work strategies should apply to identity endurance as well (see Ashforth [2001] and Ashforth et al. [2008] for reviews of these strategies). For instance, affirming positive identity attributes (Elsbach \& Kramer, 1996; Lawrence \& Suddaby, 2006; Steele, 1988) and making negative comparisons with alternate identities (Angus, 1993; Zilber, 2002, 2009) might help a valued identity to endure. The identity work literature has, however, mainly been theorized at the individual level of analysis and thus does not provide many pointers as to how (collective) organizational identity work might operate. Jumping between levels of analysis is a recurring challenge in much organizational identity research (Corley et al., 2006) and one that applies to the research question we investigate as well.

A more relevant set of answers to the identity endurance puzzle might therefore come from the organizational identity management literature. With its clear organizational focus, this literature provides clues to how identity work might proceed at the collective level (Dutton \& Dukerich, 1991; Gioia et al., 2010; Pratt \& Foreman, 2000; Ravasi \& Schultz, 2006). It has been posited that at the broadest level, organizational cultures enable organizational identity work, and by extension possibly the endurance of organizational identities (Dutton et al., 1994; Hatch, 2005; Ravasi \& Schultz, 2006). For instance, a wide 
range of common organizational cultural markers such as artifacts (Appadurai, 1986; Bechky, 2003; Pratt \& Rafaeli, 1997) and policies or procedures (Feldman \& Pentland, 2003; Selznick, 1957) provide opportunities for sense creation and can help manage identities. ${ }^{1}$ Alongside these common organizational ways to manage identities, moreover, more targeted managerial responses have also been documented. For example, when dealing with multiple identities, compartmentalization and aggregation (Pratt \& Foreman, 2000) offer ways to manage identities and might help them to endure. Though a variety of identity management strategies have been documented, most are set in the present. Identities are rarely, however, only set in the present. They are part of ongoing historical constructions and collective memories. Thus, although scholars' cumulative knowledge of identity work is considerable, its specific relationship to an organization's history, particularly its collective memory, remains neglected.

A main reason to explore this intersection is that the literatures on organizational identity and collective memory share the assumption that "imagined communities," whether historical or organizational, bind members together. Imagined communities are communities that are largely constructed by members through historical projects as opposed to face-to-face interactions (Anderson, 1991). Imagined communities, such as Irish-Americans in the United States or Armenians worldwide, provide their members with a sense of social belonging and identity. Such communities typically emerge when a community's size, geographic dispersion, or life span limits the members' ability to engage in the face-to-face construction of group identity. Most research on imagined communities has focused on national and ethnic groups, yet there is increasing recognition that other communities, including economic organizations, are no less imagined and historically constructed than nations (Jenkins, 2008). For instance, the "Amway spirit" and the "HP way" typically transcend the referenced firm's contemporary identity. Examining historical projects that sustain imagined communities can be particularly fruitful in the case of organizations that exist over long periods, and such examination may provide keys to identity endurance.

\footnotetext{
${ }^{1}$ Limiting staff turnover rate is, for instance, an example of an organizational policy that might ensure continued identity enactment (Anand, Manz, \& Glick, 1998: 809).
}

\section{COLLECTIVE MEMORY AND IDENTIFY ENDURANCE}

Collective memory has been defined as a reconstruction of the past that adapts images of ancient facts to present beliefs (Halbwachs, 1992). It is a historical construction (Olick \& Levy, 1997: 922) and, as Coser noted in his introduction to the work of Halbwachs, it requires repeatedly "imaginatively reenacting a past” (Halbwachs, 1992: 24). Collective memory entails numerous facets, including, for instance, ceremonial activities (Mosse, 1975), incorporated practices (Connerton, 1989), and traditions (Hobsbawm \& Ranger, 1992). Our focus in this article is only on the rhetorical expression of collective memory, since this facet is most amenable to historical study. Longitudinal data on ceremonies are, for instance, harder to collect. Collective memory, more broadly, is part of a community's "moral and intellectual framework" (Schwartz, 2000: 8) and confers identity on individuals and groups alike (Halbwachs, 1992). It is an active pursuit that allows "mnemonic communities" to cohere and adapt (Misztal, 2003; Schwartz, 2000; Wagner-Pacifici \& Schwartz, 1991) and has been posited to be "a central, if not the central, medium through which identities are constituted" (Olick \& Robbins, 1998: 133). It has even been suggested that without collective memories, communities would likely not persist: a "real" community is "a 'community of memory,' one that does not forget its past" (Bellah, Madsen, Sullivan, Swidler, \& Tipton, 1985: 153). In the same manner that organizational identities can be viewed as socially constructed, collective memories can be seen as historically constructed (Olick, 2007: 90).

Despite sharing similarities in approaches, collective memory and organizational identity scholars rarely intersect. Empirical research on collective memory has concentrated on only a few social groups, primarily on families, ethnic and religious groups, and nations, even though theoretical scholarship has repeatedly identified organizations as important and understudied mnemonic communities (Zerubavel, 1996). Topical foci that have come to define the field of memory studies include national monuments and the historical trajectories of public figures (for general overviews, see Misztal [2003], Olick [2003], and Olick and Robbins [1998]). Yet the collective memory lens applies just as forcefully to organizations, notwithstanding the scant attention they have received to date. Meanwhile, organizational analysis has largely overlooked the role of collective memory in its own research agenda (Rowlinson, Booth, Clark, Delahaye, \& Procter, 2010). An influential article by 
Walsh and Ungson (1991) generated a surge of interest in organizational memory, but this literature has mainly treated memory as a fairly static product rather than a historical construction (Ackerman, 1998; Argote, 1999; Feldman \& Feldman, 2006; Huber, 1991; Moorman \& Miner, 1998; Walsh, 1995). (For an example of a static approach, see Casey's [1997] study of a substance abuse organization's collective memory.) This line of research has also considered memory work largely uninfluenced by broader historical trajectories and context (Benkhard, 2000). In other words, the notion that "remembering is not an activity that can be bracketed out as either an independent or a dependent variable" but is "both the medium and the outcome of social figurations generally" (Olick, 2007: 118) has been less explored in organizational settings.

Collective memory in particular has been surprisingly missing from the discussion of identity endurance. A first reason for this neglect might be a broader lack of historical awareness in organization studies (Daniel, Arzoglou, \& Lamont, 2011; Salaman, 1978; Smith, 1990: 88). Recent calls to study organizations (here, their identities) from a more historical perspective underline this limited awareness (Schneiberg \& Clemens, 2006; Tsoukas \& Chia, 2002; Ventresca \& Mohr, 2002). With regards specifically to organizational identity research, besides a 25-year study of a Danish producer of audiovideo systems (Ravasi \& Schultz, 2006) and a 10-year study of a digital photography company (Tripsas, 2009), only rarely have scholars considered extended periods. Most studies tend to follow crosssectional designs in which the past is interpreted from a single, present point in time, rather than longitudinally examined as a potentially shifting history. And the few studies that do not confine their analysis to single points in time tend to encompass relatively short time spans-for instance, 2 years during a corporate spin-off (Corley \& Gioia, 2004) or 8 years of identity formation (Gioia et al., 2010).

A second reason for the neglect of collective memory in organizational identity studies might be that the identity literature remains largely methodologically reliant on simultaneously collected interviews. Rather than a collective memory, such interview data yield a "collected memory" (Rowlinson et al., 2010: 78). Organizational memory is treated as the aggregate of the concurrent memories of members of an organization. The studies therefore focus more on individuals' ex post exploration of the past than on the ongoing study of a constructed collective memory. As illustrations, past scholarship has emphasized the importance of con- sidering organizational "biographies" (Kimberly, 1987) or "nostalgia" (Brown \& Humphreys, 2002) when analyzing organizations. Yet these and other studies typically rely primarily on a set of individual interviews conducted over a short period of time to study history (for other examples, see Biggart [1977], de Holan and Phillips [2004], and Kimberly and Bouchikhi [1995]). In that respect, the observation that "collective memory lacks solid empirical footings" (Glynn, 1997: 147) in organization studies still holds true today. Thus, the neglect of collective memory as it relates to identity might be partly explained by such methodological choices.

Yet the potential for links between collective memory and identity endurance over extended periods appears promising. Emerging research on a firm's "rhetorical history" or "the process by which managers skillfully impose meaning on a firm's past" (Foster et al., 2011: 104) points to such potential. Building on work emphasizing human agents' roles in interpreting and shaping a firm's past (Brunninge, 2009; Ericson, 2006; Gioia, Corley, \& Fabbri, 2002; Holt, 2006), scholars have underlined the possibly generative nature of such history. For example, at given moments in time, firm members can use a rhetorical history to legitimize or delegitimize specific strategic options (Brunninge, 2009). Similarly, they can rely on such history to build external competitive advantages (Foster et al., 2011). Although these studies have mainly focused on external audiences for identities, paying attention to internal audiences is equally important. Alongside a firm's external strategic partners (Ericson, 2006) and its customers (Holt, 2006), internal firm members also constitute key audiences for these histories (Suddaby, Foster, \& Quinn-Trank, 2010: 159). Once internal members develop shared understandings about their firm's history, they may uphold the firm's identity.

Rhetorical histories are commonly associated with remembering, but forgetting also needs consideration. Forgetting is integral to all human systems, including organizations. Far from disrupting "organizational narrative which ceases to be a coherent story" and resulting "in organizational identity loss" (Ciuk \& Kostera, 2010: 187), forgetting can prove quite generative and essential to maintaining a particular organizational identity over longer periods of time. As Douglas noted, certain things always need to be forgotten for any system to work. "There is no way of paying full attention to everything" (Douglas, 1986: 76). She is not alone in highlighting the necessity to continuously forget: Halbwachs was among the first to note the affinity between remembering and forgetting-or the "de- 
formation of certain recollections" (Halbwachs, cited by Misztal [2003: 113]). In fact, many experimental studies have noted that acts of remembering prompt the forgetting of related materials (Anderson \& Bjork, 1994; Anderson \& Spellman, 1995; MacLeod \& Macrae, 2001). In a firm's rhetorical history, forgetting might therefore prove a key facet of the firm's identity endurance.

\section{RESEARCH SETTING AND TEMPORAL BRACKETING}

To understand how organizational identities endure, we study the repeated enactment of a key element of a given organization's identity over nearly 50 years. In particular, we examine how the national identity of Société Nationale d'Études et de Construction de Moteurs d'Aviation (Snecma), France's largest aircraft engine manufacturer, endures in a context of growing international complexity. By "national identity," we mean the shared belief that a given organization helps a nation retain its "grandeur," or what the historian Hecht, in her study of the French nuclear industry, called a country's "radiance" (1998: 2). National identities are understood as symbolic constructs that can be disconnected from geographical boundaries (Anderson, 1991; Nora, 1996) and are in large part imagined by organization members (Ailon-Souday \& Kunda, 2003). In our context, as in Hecht's case, "Frenchness" is associated with technological prowess and sovereignty. This definition of Frenchness is specific to the setting we studied: it is the way Snecma employees appropriate a cultural form that they share with others, yet interpret differently (Chartier, 1985: 688).

Snecma was founded in 1945 by the French government through an executive order of General de Gaulle (Danel \& Cuny, 1978). On the strength of a solid domestic position, thanks in part to the government-backed mandate to increase France's technological prowess, Snecma has become one of the four dominant actors in the global aeronautics industry (both military and civilian), alongside General Electric (GE), Pratt \& Whitney, and RollsRoyce. Intermittently in its more than 50-year history, Snecma has experienced extended periods of foreign involvement that have been essential to its survival. ${ }^{2}$ Although the collaborations helped Snecma sustain its technological leadership, some Snecma employees also saw them as a dependency that could undermine the firm's leadership. Explor-

\footnotetext{
${ }^{2}$ In 2005 Snecma became part of a larger French industrial conglomerate.
}

ing how the firm has handled these potential challenges to the continuity of its national identity offers a window into the interplay between collective memory and organizational identity.

Our analysis focuses on two distinct periods in Snecma's history. This temporal bracketing strategy allowed us to constitute comparable units of analysis for the exploration and replication of theoretical ideas (Langlay, 1999: 703-704). The company's first substantial encounter with a foreign presence occurred in 1945-70, the post-World War II era following its founding in 1945, when German engineers played a crucial role in rebuilding the French aeronautics industry and, specifically, in developing Snecma's expertise in military airplane engines, most notably the ATAR engine. The second substantial encounter spanned 1970-2000, when Snecma and GE collaborated heavily on a family of civilian aircraft engines, particularly the CFM56 engine (Hedden, 2004; U. S. General Accounting Office, 1994). Though Snecma has engaged in other foreign collaborations, the two collaborations discussed here have been the most extensive and salient in terms of outcomes and level of involvement. (The firm's other collaborations were mere licensing agreements or were less commercially important than the collaborations selected for analysis.) For a summary of Snecma's major foreign collaborations, see Figure 1.

\section{DATA AND METHODS}

The idea for this study originated from a set of interviews conducted by one of the coauthors for a separate project with Snecma aeronautics retirees. During the interviews, comments about various aspects of the French aeronautics industry's nationalism and history kept consistently reappearing. The persistence of these themes over generations of employees surprised us, especially in light of the highly international character of the contemporary aeronautics industry, and triggered our interest in the question of identity endurance, leading us to design a theory elaboration exercise in which we used past literature on identity endurance as a springboard for laying out potential new lines of research and for directing our data collection "in service of discovering" a new and hopefully more encompassing theory (Strauss, 1987: 306).

We gathered data from three types of sources for our study: (1) archived company internal bulletins, (2) transcribed interviews with Snecma retirees, and (3) other archived Snecma materials held at the French national library, Bibliothèque Nationale de France. Our primary data sources were company internal bulletins, titled "Snecma Informations," 


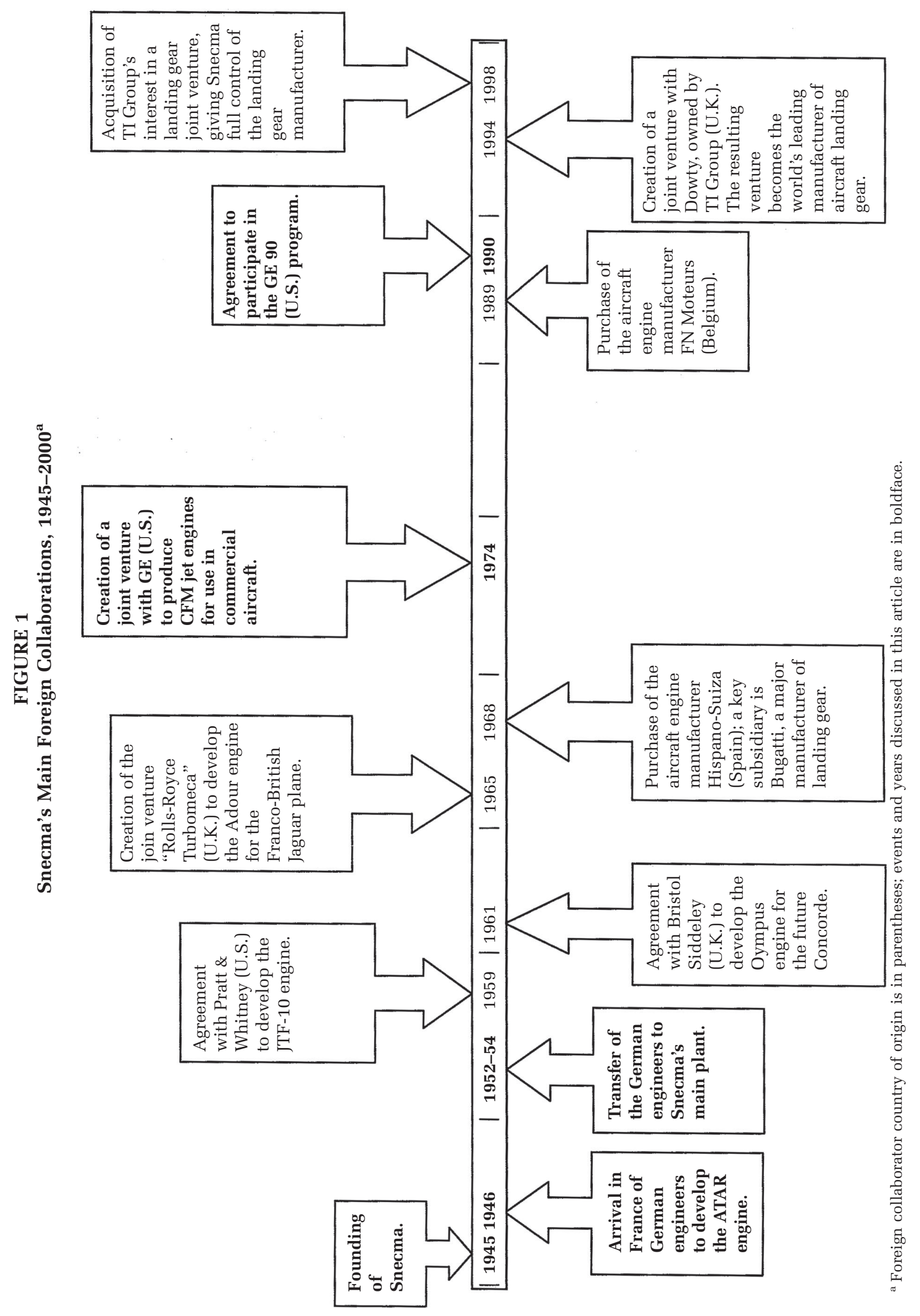


held by The Musée de l'Air et de l'Espace, an aeronautics museum. Such bulletins are by no means the sole source of shared organizational identity, but they do represent a coherent and sustained effort on the part of Snecma's leadership to fashion a shared discourse for its members. The bulletins are crucial symbolic devices capturing a constructed identity (Pratt, 2003); they act as organizational artifacts providing meaning for members and reinforcing social identity (Bechky, 2003). They also exemplify the type of print media that Anderson (1991) identified as instrumental in creating an imagined community, namely, media that allow for a shared sense of belonging for multiple generations of community members. These bulletins therefore constitute a form of collective memory: one that moves beyond a strictly methodologically individualist approach to memory (Rowlinson et al., 2010).

Moreover, the bulletins constitute a unique source of systematic data that are consistently available for the unusually long period that our study encompasses (close to 50 years). The bulletins were written over the years by a succession of more than a dozen different editors and approved by Snecma's top management. Published several times a year and disseminated to all employees, the bulletins reported on Snecma's industrial activities, new technical projects, air shows, and company developments and provided practical information on housing, health coverage, promotions, and the like. Bulletins published between 1953 and 1982 are typically around 8 pages long; by the mid-1980s, the number of pages rises to 20 or more. From 1953 to 1999, Snecma produced 347 company-wide bulletins, the vast majority of which (89 percent) are conserved at the museum (only 38 are missing). We analyzed all 309 available bulletins.

Second, we relied on interviews with 70 retirees (representing a variety of functions) who worked at Snecma from the 1970s to the 1990s. The interview protocol, initially designed to elicit data on the meaning of work, was sufficiently open to allow interviewees to discuss others topics, including Snecma's history. The interview sample was first constructed as a snowball sample and grew through direct mail solicitation. It included representatives from all main occupational groups present at Snecma (e.g., factory workers, engineers, managers). A formal call for interviews with retirees was published in Snecma's main factory newsletter, and individual letters requesting interviews were then sent out to 650 randomly selected retirees. Because we did not rely on theoretical sampling (e.g., selecting a set of interviews collected longitudinally over a 50 years rather than simultaneously), we treat the interview data only as a secondary source. With the interviewees' consent, interviews were tape-recorded and transcribed. When informants declined to be taped, extensive notes were taken. The interview protocol contained, in particular, the following questions: "What did your work entail?" "Whom did you work with?" "Can you tell me about Snecma's history?" "Am I missing out on important issues? If so, could you describe them?"

Third, we reviewed all 71 publicly available Snecma-related print publications-such as company, labor council (an elected employee body), and employee documents-by searching the indexed files of the French national library using "Snecma" as a keyword. (French publishers are legally required to deposit at the library all of their publications.) The publications, totaling 2,768 pages dated 1949 to 2007, ranged from a standalone company leaflet to more consequent studies of Snecma's main union or engines. Snecma employees or close observers mainly produced this supplementary archive, and as such it reflects their perception over time of the official organizational identity. As have past historical researchers, we combined sources to contextualize the primary data and uncover key meaning structures (Gioia et al., 2010; Rao, 1998; Weber, Heinze, \& deSoucey, 2008).

Our analysis centers on one enduring aspect of an organization's identity (its national element) from the main vantage point of one key source of organizational identity (the projected official identity conveyed via internal bulletins). We have focused on the national element of Snecma's identity because the interviewees repeatedly and consistently emphasized this dimension during the interviews. It was through the triangulation of our primary data (the bulletins) and the two additional sources (interviews and public archival documents) that we inductively identified the two foreign collaborations (with German engineers and with GE) as crucial events relating to national concerns. With an eye toward theory elaboration and focusing on Snecma's national identity, we systematically read the entire set of bulletins and identified all references to the German engineers and the GE collaboration. Such references took the form, for instance, of progress reports on joint projects and narratives about joint Snecma-GE industrial activities. (There were, however, many references to the outcomes of the collaboration-for instance, descriptions of the CFM56 engines-that did not mention the American or German input.)

We then engaged in a broader analysis of the bulletins that entailed generalizing from specific accounts to broader themes through iterative cod- 
ing of the bulletins. We initially identified broad themes by reading randomly selected bulletins to identify the main topics covered. We then used these topics (such as military engines) as coding categories. When new topics emerged (such as Concorde-related activities, beginning in 1963), new categories were added. We then consolidated the categories into broader ones while also keeping close track of coverage of the key foreign collaborations. The final list of main categories included (1) internal affairs, such as promotions, benefits, and the like; (2) industry overviews, such as discussions of markets, general competition, industry trends, and air shows; (3) German-related activities, including coverage of the ATAR engine, but without mention of the collaboration; (4) German collaboration coverage; (5) GE-related activities, including coverage of the CFM56, CF6, GE36, and GE90 engines but without mention of the collaboration; (6) GE collaboration coverage; (7) other Snecma industrial activities activities, including coverage of all military engines, Concorde activities, space-related activities, nuclear activities, and other activities such as maintenance; and (8) new technologies not yet assigned to a specific engine. In addition, when foreign collaborations were discussed (namely, in categories 4 and 6), we noted whether elements of Snecma's national identity were simultaneously addressed.

Since we did not directly collect these data, we had two coders fluent in French independently analyze the content of each bulletin. (The initial intercoder reliability rate was 86 percent; remaining disagreements were resolved through discussion.) To assess the relative salience of each category and, by extension, to understand the mix of coverage at Snecma over the years and its constructed collective memory, we calculated the number of pages devoted to each category in all 309 bulletins. The decision to quantify qualitative data was partly driven by the volume of our data (Pratt, 2009: 858). For any given year, the percentage of coverage devoted to a given category was calculated as the number of pages devoted to it divided by the total number of pages published that year. (In 1974, for instance, out of a total of 80 published pages, 6.25 pages were devoted to GE-related activities. Thus, GE-related activities accounted for 7.8 percent of coverage that year.) Finally, we returned to the interviews and other archives to identify any references to France and foreign collaborations to contextualize the bulletin's content.

We begin our analysis by describing the origins of Snecma's national identity and its endurance over time. Second, we document the two major foreign components of this endeavor and the chal- lenges they raise to Snecma's national identity. Third, we describe the threat of identity contradictions arising from these collaborations. Fourth, we analyze the collective memory of these foreign involvements, focusing on the ongoing strategies in the firm's rhetorical history devised to make sense of these contradictions. More specifically, we show how Snecma's official history structurally omits potentially contradictory aspects of the firm's past or attempts to preemptively neutralize them with cues of the national identity. In both cases of foreign collaboration, national identity endurance in part proceeds through repeated forgetting in the firm's ongoing rhetorical history. Thus, the firm's collective memory offers a venue for engaging in organizational identity work. Finally, we discuss the study's implications for organizational identity and collective memory research.

\section{SNECMA'S ENDURING NATIONAL IDENTITY}

The importance of national identity for Snecma has roots in the organization's unique genesis. The main entity integrated into Snecma at its inception, Gnome et Rhône, was one of only two French firms (along with the automotive manufacturer Renault) subject in 1944-45 to explicitly "patriotic" postwar nationalizations, or, as historians have labeled them, "sanction-nationalizations," which were imposed for "unpatriotic" behavior during World War II- essentially, working too closely with the German occupiers (Audrieu, 1987: 252; Hamdouch, 1989: 19). Snecma's origins thus saddled it with a heavy onus of proof of patriotism. General de Gaulle made this clear when he created Snecma in his capacity as chairman of the Provisional Government of the French Republic: "The patriotic consciousness necessitates a complete reorganization of the company [Gnome et Rhône, the precursor to Snecma]" (Journal Officiel de la République Française, 1945). ${ }^{3}$

Over nearly 50 years, multiple sources suggest that Snecma's identity has remained rooted in a national discourse. Historically, the French aeronautics industry has been entwined in the nation's ongoing pursuit of global technological leadership. As a state-owned company from 1945 to 2005, Snecma was central to this pursuit. Like firms in the nuclear industry, firms in the aeronautics industry were expected to demonstrate their "Frenchness" through their technological prowess, and their technological prowess came, by the same to-

\footnotetext{
${ }^{3}$ This and all subsequent translations from French are by the authors.
} 
ken, to define and reinforce "Frenchness" (Callon, 2009; Hecht, 1998: 40). A close observer of the aeronautics industry explained that it is "a tradition in France, since the origins of aviation, that the needs of the country are served by a national aeronautics industry" (Carlier, 1986: 1). The desire for such a capability was also coupled, however, with a goal of global leadership.

By the late 1950s, some French citizens resented the preeminence that the United States was slowly gaining in many sectors, including aeronautics (Hecht, 1998: 39-40; Kuisel, 1997). Snecma's central Labor Council members, for instance, wrote in 1959 about what they called the "crisis of French aeronautics and its dramatic consequences at Snecma" (Snecma, 1959: 1). The Labor Council charged that the government was investing too little in the industry and that a foreign nation (the United States), via NATO, had "limited" France's aeronautics potential. Again in 1960, Snecma's Labor Council warned of a "nefarious agreement" with the United States that rendered most French aeronautics firms "more or less under the control of the American corporations" (Snecma, 1960: 1). By 1973, the Labor Council's warnings had become even more precise: Snecma should not become "a subcontractor to GE” (Snecma, 1973: 2). An unequal cooperation with GE in which Snecma played second fiddle directly challenged Snecma's national identity.

Snecma was not the sole organization entrusted with the task of developing "French" capabilities in the aeronautics industry, but with respect to plane engines it alone largely inherited that task after World War II. Thus, the understanding that Snecma had originated as part of a national endeavor was central to its identity (Carlier, 1997a; Chilin \& Mullié, 2000; Rozenblatt, 1989). As industry observers have pointed out, the creation of Snecma served in part to fulfill two agendas on which there was widespread agreement: an ideological one (the importance of developing a national industry) and a technical-economic one (the ability to manufacture efficient civilian and military engines) (Rozenblatt, 1989). As a company that was state-owned for most of its history, founded by a government decree, and associated with the national defense industry, Snecma was emblematic of this broader national ideological agenda. In one of Snecma's earliest annual reports, dated 1956, a presentation on the company's prevailing status began with a comparative table of manufacturers organized by national affiliation (United States, United Kingdom, France, and Canada), number of employees, and square feet of installed plant capacity, thus emphasizing national rivalries. The report reassured readers that
Snecma possessed "a fully autonomous and pathbreaking technology allowing it to be counted among the leading engine manufacturers in the world" (Snecma, 1956: 18-19). Such patriotic claims still permeated Snecma as recently as the mid-1980s: in a 1986 speech to a mixed civilian and military audience, a Snecma representative asserted that the firm had fulfilled the mission assigned to it in 1945, namely, to "reposition France in the arena of aeronautics engines" (Bodemer, 1986: 117).

These post-World War II national aspirations still prevail. Though the contemporary aeronautics industry and, specifically, the manufacture of plane engines, is among the most global of industries (sellers are concentrated, products are fairly standardized, and many customers purchase across borders), nations still compare themselves with each other (Greenberg, Grunberg, Moore, \& Sikora, 2010). Recently, for instance, members of the French National Assembly called for a commission to debate the closure of an aeronautics plant in part to protect the country's "capabilities and world rank, as well as its development potential" (French National Assembly, proposal no. 2608, October 19, 2005). Because the development of new aircraft and engines is an extremely costly and economically risky enterprise, it can no longer, however, be pursued under the aegis of individual manufacturers. Thus, joint ventures, strategic alliances, and government-approved mergers that often transcend national borders have come to dominate the aeronautics industry. But the fear of losing national leadership continues to shape the identity of organizations in the industry, especially in the case of France, given the close link between technological prowess and French national identity (Hecht, 1998).

A vast majority of the Snecma interviewees spoke about the need to maintain France's leadership when asked to describe the firm's history. As one interviewee typically noted, "In the 1960s in France, no firm was able to build needed tools for the aeronautics pursuit. We were forerunners. Only the Americans could make similar claims." National comparisons were integral to the remembered history. Similarly, another interviewee recalled that during the 1950s, space conquest was an "adventure in which a select group of countries were trying to fly the best engines." He added, "Snecma's success was France's success." Overall, the combined sources suggest that Snecma's national identity was inherited at the organization's birth, reiterated over time, and internalized by certain employees. The "patriotic consciousness" that justified Snecma's creation in 1945 proved a fairly 
enduring element of the firm's organizational identity.

\section{SNECMA'S UNEASY RELIANCE ON FOREIGN EXPERTISE}

What General de Gaulle did not mention in 1945 was that France at the time lacked the expertise to build the plane engines that its military wanted; his speech thus created inconsistencies and tensions between Snecma's identity and its actual technological prowess. De Gaulle's administration therefore sought the cooperation of a leading German aeronautics engineer, Herman Oestrich, former technical chief of the turbojet program at Bayerische Motoren Werke (BMW), to enhance Snecma's technological expertise. Similarly, starting in the 1970s, another foreign collaboration proved crucial to the development of Snecma's expertise. By cooperating with the American firm GE, Snecma successfully positioned itself as a leading manufacturer of civilian engines. Although the German and GE collaborations were instrumental in developing a national aeronautics capability, they also were direct reminders of the limits of Snecma's technological leadership.

Snecma's first major reliance on foreign expertise occurred right after World War II, when the French government hired 120 German and Austrian technicians and engineers (commonly referred to as "German engineers") to jump-start the French aeronautics industry (Lamouche, 1999: 138). The German engineers were headed by Oestrich, whose attainments included development of the engine that powered Germany's plane credited with contributing to France's initial defeat during World War II (Bodemer \& Laugier, 1996). France was not alone in recruiting German engineers into its national industries. Many other countries, including the United States and the U.S.S.R, also recruited German scientists (Carlier, 1997a: 11-16; Hunt, 1991). Though courted by the British and Americans, Oestrich opted to develop a turbojet engine for the French. The new engine was initially developed in French-occupied Germany, but the French government soon decided to bring his team to France in a 90 percent subsidiary of Snecma located in small town in central France called Decize. By 1954, Snecma's management transferred the German engineers from relative confinement in Decize and integrated them into the Snecma plant at Villaroche.

Of the various German workers brought to France after the war, the Oestrich group had a distinctness that lay in its size and its impact on Snecma (Bohnekamp, 2002: 40-41). The German engineers al- most single-handedly positioned Snecma as a crucial supplier to the French Air Force. By 1948, on the strength of German expertise, Snecma produced a turbojet engine known as ATAR. The engine was somewhat deceivingly named for the Ateliers Aéronautique de Rickenbach (ATAR), a site in a town in French-occupied Germany where Oestrich and his team had worked before coming to France. The design of the ATAR engine, however, could be traced directly to the Berlin BMW plant where Oestrich's group had originated. Moreover, the Villaroche plant in which the German engineers ended up working gradually became one of Snecma's largest, employing close to half its workforce. The engineers played a key role in the development at Snecma of "French" expertise on military airplane engines. Thus Snecma's professional strength in turbojet engines relied initially on German expertise.

In 1969, Snecma again relied heavily on foreign expertise when it began collaborating with GE to produce civilian engines. By the early 1970s, the collaboration produced the first of a successful line of civilian engines, the CFM56. In 1972 an improved version, the CFM56-2, was launched by a 50/50 joint partnership known as CFM International. The assembly of CFM56 engines took place at Snecma using preassembled elements arriving from GE plants based in the United States. GE contributed its expertise in the development and manufacture of the core engine, namely the turbine or the most complex part of the engine, also known as its "hot" or "noble" part (Anteby, 2008: 54). By contrast, Snecma essentially contributed its knowhow on the engine's "cold" components, the fan and the low engine-compressor, and its noise reduction expertise (Bernard \& Raffy, 1975). Overall, Snecma controlled only 27 percent of the total value of the engine; GE controlled most of the remaining value, with some marginal control assigned to a German manufacturer. This distribution of control was based on "the manufacturing experience of each partner," a tacit acknowledgement of GE's superior experience on that engine (Snecma, 1973: 6). Moreover, when, briefly, the GE cooperation seemed in jeopardy, Snecma deemed the situation "alarming," not only for the project, but also for the firm's own future (Snecma, 1972: 6). Snecma crucially needed the technologies developed by GE. This situation echoed what Snecma had experienced after World War II, when Germans engineers controlled the initial technology for the ATAR's hot components.

GE gradually became a crucial partner/competitor for Snecma in the international civilian aeronautics market between 1970 and 2000. By 2000, 
the CFM56, produced by both companies, had captured close to 70 percent of the primary market for civilian plane engines in the $18,000-45,000$ pound thrust category (the main segment for civilian engines as of 2000). This engine dominated the market for civilian engines in its category for several decades, and Snecma and GE shared in its success. By 2006, civilian engines represented 82 percent of Snecma revenues (Safran, 2006: 24). One rare public indicator of Snecma's dependence on GE-related activities is the fact that, by Snecma's own estimates, 34 percent of its revenues in 2004 flowed from GE-related collaborations (Snecma, 2004: 34). As in Snecma's early years, foreign components (this time not in terms of workforce but in terms of material parts and know-how) were contributing significantly to Snecma's success.

\section{THE THREAT OF IDENTITY CONTRADICTIONS}

Although foreign collaborations were occasionally depicted as evidence of France's technological prowess (Chilin, 2000a: 130), more often they were seen as conflicting with Snecma's national identity, or leading to what scholars have labeled "contradictions" within and between social systems (Creed, DeJordy, \& Lok, 2010; Creed \& Seo, 2002). "Frenchness" was assumed to come only from "within," not from external imports (Boorstin, 1989: xvi). (See Hecht [1998: 328-329] and Djelic [1998] for similar perceptions of foreign collaboration in other industries.) In an acknowledgment of this contradiction with reference to another foreign partnership, the company-wide bulletin noted: "We signed an agreement ... now more than a year ago. A lot has been said. While some put forward the technical and commercial advantages of such an association, others saw it as a regrettable intrusion of a foreign firm in our activities" (Snecma, 1975: 3). Besides being seen as "intrusions," the foreign collaborations could also suggest a technical inferiority that challenged Snecma's national identity.

The French government hired the German engineers partly because it viewed the French Air Force, and the French aeronautics industry, as inferior to the forces of its enemies and allies during World War II (Fridenson \& Lecuir, 1969; Vivier, 1997). Thus, the presence of the German engineers at Snecma underlined the French aeronautics industry's limitations. The fact that these hires were former enemies exacerbated the uneasiness about the collaboration. When the German engineers first relocated to France, Snecma's management brought in a prominent national political leader to deliver a speech to Decize residents asserting that "those who criticized the arrival of Germans at Decize can only be collaborators" (Carlier, 1997b). Snecma's national project justified tolerating the presence of former enemies whose work served the project; it was the critics of this arrangement who were labeled unpatriotic. This speech depicted the foreign collaboration as a possible answer to Snecma's technical inferiority, but also revealed Snecma's limited capabilities, and by extension, its fragile national identity.

Similarly, the GE collaboration proved partly contradictory with Snecma's national identity. The collaboration was officially depicted as "recognition by GE of the value of being associated with Snecma and of our technical and industrial capabilities" (Snecma, 1990: 3). But the need to maintain an independent national aeronautics capability was voiced as soon as the cooperation started (Snecma, 1970: 2).

Some observers also noted that GE was more interested in the financial investments that the French state-owned company could promise up front, and in the possibility of export to Europe, than it was in Snecma's technical expertise (Comité pour l'Histoire de l'Aéronautique, 2003: 76). Moreover, the U.S. administration refused at first to allow export of GE's core engine technology to Snecma (Bonnet, 1996: 63)—suggesting that it perceived Snecma's technology as less advanced.

When the CFM56 collaboration was officially launched in 1971, Snecma's president warned employees that "we should not show ourselves inferior” to General Electric (Snecma, 1971: Supplement). Implicitly, such inferiority would tarnish Snecma's national identity. Thus, Snecma bulletins almost always characterized the dynamics of the relationship between Snecma and GE in terms of equality. Proclamations of a "partnership of equals" date to the early days of the CFM56 (for examples, see Snecma, 1974a: 1; 1974b: 1; and 1974c: 1). But suspicions of a sell-out to GE occasionally surfaced, signaling uneasiness regarding the collaboration on the part of the French. Snecma's technical director was asked, for instance, in a 1985 public colloquium, if Snecma's relatively small size, the siting of CFM headquarters in the United States, and the distribution of production tasks signaled "control of Snecma by GE." His answer, and the official stance consistently conveyed in the bulletins, reaffirmed that the partnership was a "50/50 collaboration" (Lachaume, 1986: 205). The claims of equality underlined the unease among Snecma members that the GE collaboration triggered. The next sections describe how-in light of these foreign involvements-through structural omissions of Snecma's past and attempts to pre- 
emptively neutralize contradictory elements of the past with national cues, the firm's collective memory helped sustain the firm's national identity.

\section{STRUCTURAL OMISSION}

The opportunity to revisit Snecma's past provided by each publication of Snecma's internal bulletins points to repeated omissions of major foreign collaborations from the historical record, and, by extension, from the firm's collective memory. The content analysis of the bulletins presented in Figure 2 shows that the firm's two most significant foreign collaborations (the German and GE collaborations) did take up a considerable share of the bulletin's coverage in the relevant time periods. However, they were overwhelmingly discussed without any explicit mention that these were foreign collaborations. In essence, the roles of the German engineers and GE in Snecma's industrial activities were routinely forgotten. Contradictory elements of Snecma's past were mainly left out from the firm's ongoing rhetorical history.

Such structural omission is particularly evident with respect to the German engineers. The history of Franco-German collaboration was common knowledge among Snecma employees and retirees, yet the internal bulletins provide sparse coverage of that past. As Table 1 indicates, of the 5,622 pages of bulletins we analyzed, fewer than 5 pages $(0.1 \%)$ explicitly mention the German contingent. A photograph of Oestrich-an identifiably Germanic name-with the byline "Director of the Technical Group in Charge of Turbo Engines" appeared in the first company-wide Snecma bulletin in 1953, alongside portraits of 14 other executives (Snecma, 1953: 8-9). At Oestrich's retirement in 1960, an internal memorandum signed by Snecma's director praised his "leadership," "remarkable technical abilities," and his contributions to "the difficult Franco-German collaboration." At his death, a moving tribute, including an account of his early trajectory in Germany, appeared in a bulletin (Snecma, 1973: 1). But apart from these sporadic references, the German collaboration left little trace in the bulletins.

Additional sources also suggest the extent of the German engineers' structural omission in the company's rhetorical history. A former Snecma union representative wrote about what he saw as Snecma's management's general, "more or less conscious desire to 'erase' the German presence responsible for the ATAR [engine]" from Snecma's collective memory (Chilin, 2000b: 84). An illustration of such omission occurred in the early 1980s, at the retirement ceremony of a French engineer who had worked closely with the Germans in Decize and, then, at Villaroche. His supervisor made a speech underlining the fact that the retiree had entered the industry as a "mere draftsman." The retiree was, however, a graduate of a German aeronautics engineering school that he attended during World War II after being taken by the Germans. His supervisor was aware of this. Both his supervisor and he preferred to omit the German element of his past. Similar omission also occurred in more recent times. For instance, in late 1999, when Snecma Villaroche's plant director wished employees a happy new year, he reminded them that years earlier Villaroche had employed the pioneers of modern aeronautics: "For fifty years all the plane engines that contributed and still continue to contribute to the fame of Snecma were born at Villaroche." The plant's accomplishments, he added, made it a "jewel of the French and European aeronautics industry” (Snecma, 1999: 1). Technically, the director's phrasing was correct: all the plane engines that had contributed to Snecma's success in the previous 50 years (since 1949) had been "born" at Villaroche. But Snecma's greatest initial success, the ATAR engine, was conceived in Berlin, then Rickenbach, and finally Decize (in 1948), not at Villaroche. Thus, one of the most consequential births had occurred elsewhere and involved a contingent of German engineers as midwives-a seemingly small omitted detail.

For the GE collaboration starting in the 1970s, the physical distance to the American teams working on the CFM line of engines de facto helped downplay the extent of the foreign involvement, yet physical distance was not enough; structural omission again proved apparent in the treatment of the collaboration. Systematic examination of references to GE in Snecma's internal bulletins at a time when Snecma and GE were collaborating heavily (on the CFM56 and later on the GE90) reveals a familiar pattern of narrative omissions. Although close to 300 pages of Snecma Informations (292, or $5.2 \%$ ) were devoted to GE-related activities, only a small number of pages (18, or $0.3 \%$ ) touched specifically on the GE collaboration-providing, for instance, details on GE's work on the same engines in the United States (see Table 1). Few articles on the CFM56 mentioned Snecma's collaborative work in Cincinnati and at other U.S. GE plants, thus suggesting structural omission in Snecma's collective memory. This partial coverage is in keeping with the narrative strategy that Snecma engaged in over the years: the proper way to discuss the collaboration was to focus on its national (French) component. An article on the first orders for the CFM56-3 (an updated version of the CFM56 en- 

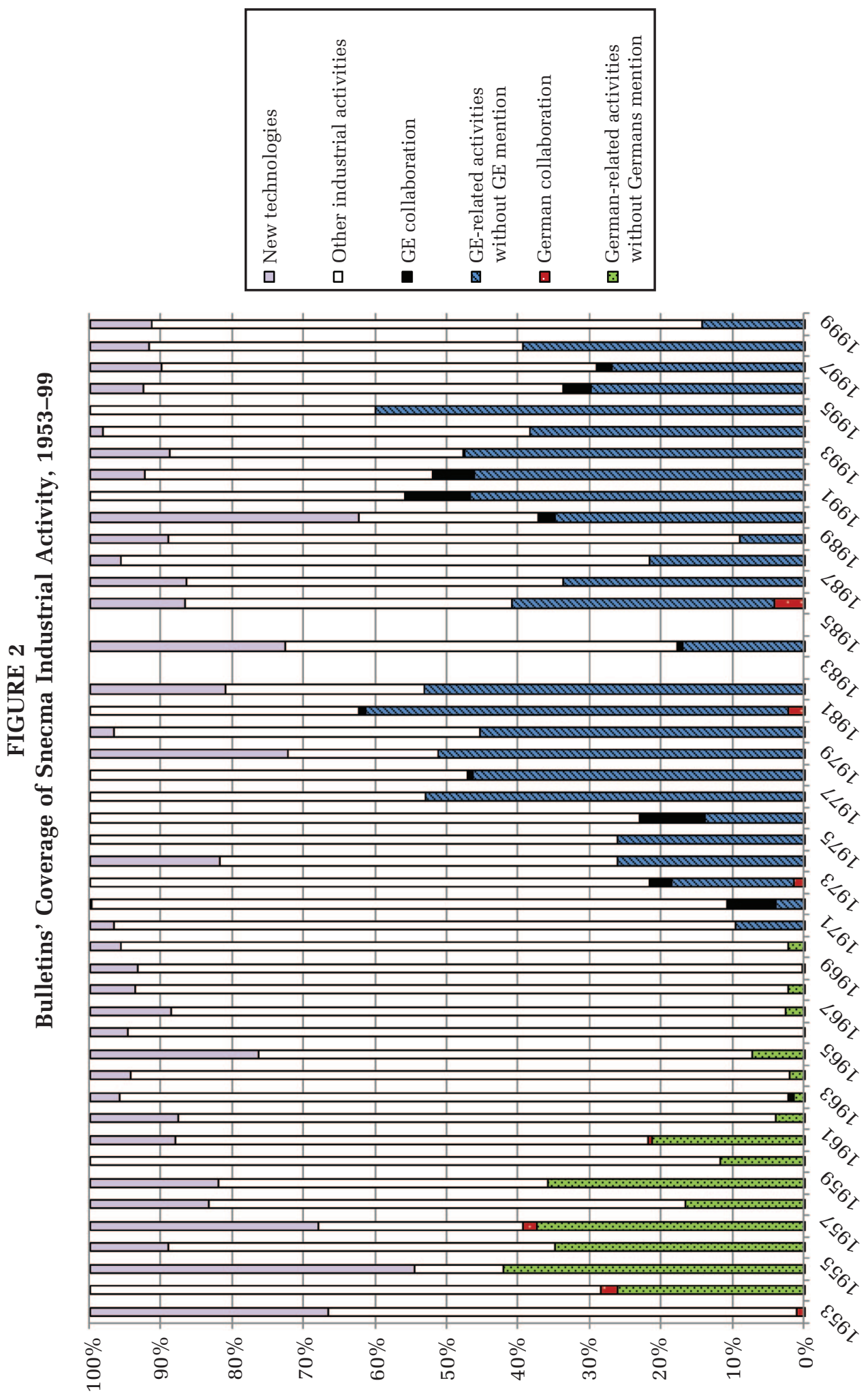
TABLE 1

Snecma Company Bulletins' Content Distribution, 1953-99 ${ }^{\text {a }}$

\begin{tabular}{|c|c|c|c|c|c|c|c|c|c|}
\hline \multirow[b]{2}{*}{ Year } & \multirow[b]{2}{*}{$\begin{array}{c}\text { Number of } \\
\text { Pages } \\
\text { Published }\end{array}$} & \multicolumn{8}{|c|}{ Percentage of Pages Devoted to } \\
\hline & & $\begin{array}{l}\text { Internal } \\
\text { Affairs }\end{array}$ & $\begin{array}{l}\text { Industry } \\
\text { Overview }\end{array}$ & $\begin{array}{c}\text { German-Related } \\
\text { Activities } \\
\text { without } \\
\text { Germans } \\
\text { Mentioned }\end{array}$ & $\begin{array}{c}\text { German } \\
\text { Collaboration }\end{array}$ & $\begin{array}{c}\text { GE-Related } \\
\text { Activities } \\
\text { without GE } \\
\text { Mentioned }\end{array}$ & $\begin{array}{c}\text { GE } \\
\text { Collaboration }\end{array}$ & $\begin{array}{c}\text { Other } \\
\text { Industrial } \\
\text { Activities }\end{array}$ & $\begin{array}{c}\text { New } \\
\text { Technologies }\end{array}$ \\
\hline 1953 & 72 & 87.5 & 0 & 0 & $0.1(0)^{*}$ & 0 & 0 & 8.2 & 4.2 \\
\hline 1954 & 282 & 84.4 & 0.7 & 3.9 & $0.4(0.4)^{*}$ & 0 & 0 & 10.6 & 0 \\
\hline 1955 & 366 & 90.2 & 4.4 & 2.3 & 0 & 0 & 0 & 0.7 & 2.5 \\
\hline 1956 & 320 & 61.2 & 14.5 & 8.5 & 0 & 0 & 0 & 13.2 & 2.7 \\
\hline 1957 & 272 & 73.3 & 7.2 & 7.3 & $0.4(0.4)^{*}$ & 0 & 0 & 5.6 & 6.3 \\
\hline 1958 & 216 & 55.8 & 33.1 & 1.9 & 0 & 0 & 0 & 7.4 & 1.9 \\
\hline 1959 & 188 & 62.6 & 16.6 & 7.4 & 0 & 0 & 0 & 9.6 & 3.7 \\
\hline 1960 & 96 & 72.9 & 15.5 & 1.4 & 0 & 0 & 0 & 10.2 & 0 \\
\hline 1961 & 104 & 74.0 & 12.4 & 2.9 & $0.1(0.1)^{*}$ & 0 & 0 & 8.9 & 1.6 \\
\hline 1962 & 104 & 54.5 & 15.1 & 1.3 & 0 & 0 & 0 & 25.4 & 3.8 \\
\hline 1963 & 96 & 43.6 & 14.0 & 0.6 & 0 & 0 & $0.3(0.3)^{*}$ & 39.7 & 1.8 \\
\hline 1964 & 104 & 44.4 & 8.5 & 1.0 & 0 & 0 & 0 & 43.5 & 2.7 \\
\hline 1965 & 104 & 45.6 & 25.2 & 2.1 & 0 & 0 & 0 & 20.2 & 6.9 \\
\hline 1966 & 104 & 45.4 & 8.9 & 0 & 0 & 0 & 0 & 43.3 & 2.4 \\
\hline 1967 & 104 & 47.8 & 9.9 & 1.2 & 0 & 0 & 0 & 36.3 & 4.8 \\
\hline 1968 & 88 & 50.2 & 8.3 & 0.9 & 0 & 0 & 0 & 38.0 & 2.6 \\
\hline 1969 & 88 & 54.4 & 11.5 & 0.1 & 0 & 0 & 0 & 31.7 & 2.3 \\
\hline 1970 & 104 & 54.6 & 10.9 & 0.8 & 0 & 0 & 0 & 32.2 & 1.5 \\
\hline 1971 & 124 & 55.0 & 18.1 & 0 & 0 & 2.6 & 0 & 23.4 & 0.9 \\
\hline 1972 & 80 & 50.6 & 8.6 & 0 & 0 & 1.6 & $2.8(2.8)^{*}$ & 36.3 & 0.1 \\
\hline 1973 & 88 & 47.6 & 12.3 & 0 & $0.6(0.6)^{*}$ & 6.9 & $1.3(1.3)^{*}$ & 31.4 & 0 \\
\hline 1974 & 80 & 61.2 & 9.0 & 0 & 0 & 7.8 & 0 & 16.6 & 5.4 \\
\hline 1975 & 80 & 69.4 & 13.1 & 0 & 0 & 4.6 & 0 & 12.9 & 0 \\
\hline 1976 & 72 & 62.7 & 7.2 & 0 & 0 & 4.2 & $2.8(1.4)^{*}$ & 23.1 & 0 \\
\hline 1977 & 80 & 68.6 & 6.4 & 0 & 0 & 13.3 & 0 & 11.8 & 0 \\
\hline 1978 & 80 & 65.0 & 15.8 & 0 & 0 & 8.9 & $0.1(0.1)^{*}$ & 10.2 & 0 \\
\hline 1979 & 80 & 54.9 & 9.1 & 0 & 0 & 18.4 & 0 & 7.6 & 10 \\
\hline 1980 & 64 & 71.5 & 6.2 & 0 & 0 & 10.2 & 0 & 11.4 & 0.8 \\
\hline 1981 & 60 & 46.0 & 17.3 & 0 & $0.8(0.8)^{*}$ & 21.8 & $0.3(0.3)^{*}$ & 13.8 & 0 \\
\hline 1982 & 24 & 62.9 & 4.2 & 0 & 0 & 17.5 & 0 & 9.2 & 6.3 \\
\hline 1984 & 40 & 56.0 & 7.5 & 0 & 0 & 6.3 & $0.3(0.3)^{*}$ & 20 & 10 \\
\hline 1986 & 110 & 73.5 & 4.7 & 0 & $0.9(0.9)^{*}$ & 8.0 & 0 & 9.9 & 2.9 \\
\hline 1987 & 120 & 40.1 & 23.0 & 0 & 0 & 12.5 & 0 & 19.4 & 5.0 \\
\hline 1988 & 122 & 73.4 & 8.2 & 0 & 0 & 4.0 & 0 & 13.6 & 0.8 \\
\hline 1989 & 103 & 64.5 & 4.5 & 0 & 0 & 2.8 & 0 & 24.8 & 3.4 \\
\hline 1990 & 184 & 57.9 & 16.1 & 0 & 0 & 9.1 & $0.6(0.6)^{*}$ & 6.5 & 9.8 \\
\hline 1991 & 161 & 65.6 & 14.0 & 0 & 0 & 9.6 & $1.9(0.6)^{*}$ & 9.0 & 0 \\
\hline 1992 & 256 & 58.4 & 11.1 & 0 & 0 & 14.1 & $1.8(0.8)^{*}$ & 12.3 & 2.3 \\
\hline 1993 & 172 & 59.5 & 9.3 & 0 & 0 & 14.8 & $0.1(0)^{*}$ & 12.8 & 3.5 \\
\hline 1994 & 172 & 62.7 & 4.7 & 0 & 0 & 12.6 & 0 & 19.5 & 0.6 \\
\hline 1995 & 40 & 50 & 12.5 & 0 & 0 & 22.5 & 0 & 15.0 & 0 \\
\hline 1996 & 116 & 50.2 & 4.3 & 0 & 0 & 13.6 & $1.7(0.9)^{*}$ & 26.7 & 3.4 \\
\hline 1997 & 128 & 45.4 & 0 & 0 & 0 & 14.8 & $1.2(0.4)^{*}$ & 33.2 & 5.5 \\
\hline 1998 & 104 & 58.6 & 6.3 & 0 & 0 & 13.8 & 0 & 18.5 & 2.9 \\
\hline \multirow[t]{2}{*}{1999} & 70 & 45.0 & 5.0 & 0 & 0 & 7.1 & 0 & 38.6 & 4.3 \\
\hline & 5,622 & 62.2 & 10.8 & 1.7 & $0.1(0.1)^{*}$ & 5.2 & $0.3(0.2)^{*}$ & 16.9 & 2.9 \\
\hline
\end{tabular}

\footnotetext{
${ }^{a}$ The years 1983 and 1985 are missing. The years 1984 and 1995 produced only two and one bulletins, respectively.

${ }^{\mathrm{b}}$ Figures in parentheses indicate the percentage of pages devoted to either the German or the GE collaboration that simultaneously discuss elements of Snecma's national identity.
}

gine) is typical of the coverage of the collaboration provided in the internal bulletins. Under the title, "First Orders for the CFM56-3: the model of the engine delivered to Boeing," the bulletin notes that
U.S. airlines such as Southwest Airlines and USAir purchased the engines and explains in detail the role the main Snecma plant played in making these models. Only a brief footnote reminds readers that 
the engine "as we all know," was developed with GE (Snecma, 1981: 2). (See Table 2, which presents excerpts representing the bulletins' main content areas, for other quotations.) The structural omission of collaborations involving the Germans engineers or GE from Snecma's collective memory helped affirm Snecma's national identity.

Added archival sources and interviews also point to similar structural omission. For instance, a chronology of Snecma's Villaroche plant from World War II to 1995 does not once mention GE (Lamouche, 1999: 200-208). In the interviews, some retirees did bring up the GE collaboration when discussing personal work interactions. Many engineers and executives, in particular, had worked closely at some point in their careers with GE counterparts. They often described the benefits they derived from those close relationships. As an example, a retiree recalled that when he visited GE facilities, he noticed "large machines, like X-ray machines, that permitted to look inside engines: we gradually adopted the same." Likewise, another retiree remarked that "Snecma started buying parts from GE that proved vital to the engine's development." Prior to that, he did not realize how "vital" they were to building engines. Yet when asked about Snecma's history, retirees tended to focus on activities and development occurring in France, with few mentions of U.S.-based activities. The use of wording suggest-

TABLE 2

Snecma Company Bulletins' Main Content Areas, 1953-99

\begin{tabular}{|c|c|}
\hline Main Content Areas & Representative Excerpts \\
\hline Internal affairs & $\begin{array}{l}\text { "Pre-retirement measures will allow volunteer employees in the trades listed below to } \\
\text { benefit from a pre-retirement funded by the firm." (1992) } \\
\text { "M. David Eidelman, formerly head of the spare parts department at the Direction of } \\
\text { materials in use, was named June 1st } 1972 \text { head of the computers department." } \\
\text { (1972) }\end{array}$ \\
\hline Industry overview & $\begin{array}{l}\text { "The Bourget airport stopped its commercial traffic and is transforming its activity." } \\
\text { (1981) } \\
\text { "1977: A very encouraging year for the Airbus A } 300 \text { : Between January 1st and } \\
\text { December 31st 1977, the Airbus Industries consortium received } 46 \text { orders, including } \\
26 \text { options." (1978) }\end{array}$ \\
\hline \multicolumn{2}{|l|}{ Industrial activities } \\
\hline $\begin{array}{l}\text { German-related activities } \\
\text { (without Germans } \\
\text { mentioned) }\end{array}$ & $\begin{array}{l}\text { "The activities for the various Snecma entities entail the study and development of the } \\
\text { ATAR . . . as well as the mass production of the ATAR 101-D." (1953) } \\
\text { "The year } 1972 \text { at Snecma will essentially see the rise in pace of the ATAR production } \\
\text { to } 20 \text { engines per month." (1972) }\end{array}$ \\
\hline German collaboration & $\begin{array}{l}\text { "The experience [of the ATAR engines] developed by the "O Group” under Dr. } \\
\text { Oestrich's leadership in Germany was remarkably transferred to France after the } \\
\text { war." (1986) } \\
\text { "In 1945, a group of } 120 \text { German engineers and technicians assembled by Mr. Oestrich } \\
\text { settled at Rickenbourg, near the Lake Constance." (1981) }\end{array}$ \\
\hline $\begin{array}{l}\text { GE-related activities (without } \\
\text { GE mentioned) }\end{array}$ & $\begin{array}{l}\text { "The first test engine [CFM56-5C2] ran at Villaroche on December 27, } 1989 \text { and has } \\
\text { since accumulated many test hours." (1990) } \\
\text { "The rebound in orders for civilian motors in } 1996 \text { led to a high rise in the } \\
\text { manufacturing pace. The number of engines to build had been double in 1997: } \\
\text { Thus creating a real challenge for the manufacturing." (1997) }\end{array}$ \\
\hline GE collaboration & $\begin{array}{l}\text { "Team GE/SNECMA: A model of cooperation. It's 2:30 in the afternoon. Second Shift is } \\
\text { just beginning at GE Aircraft Engines. Assembler Pat Scott arrives at her work } \\
\text { station in the factory floor at Evandale, Ohio, and begins assembly of a CFM56 } \\
\text { engine." (1991) } \\
\text { "General Electric: Our new partner. GE's story goes back to the star of U.S. jet industry. } \\
\text { It was in October 1942, the day the first American "jet" flew off a dry California } \\
\text { lake." (1972) }\end{array}$ \\
\hline Other industrial activities & $\begin{array}{l}\text { "The } 1980 \text { rehabilitation of the Gennevilliers mill and the } 1989 \text { launch of its extension } \\
\text { did not permit the collocation of all activities. This will be done in March 1994." } \\
\text { (1994) } \\
\text { "In the context of client support, the mission of our training center is to offer users a } \\
\text { series of courses in all aspects of our products." (1993) }\end{array}$ \\
\hline New technologies & $\begin{array}{l}\text { "Studies are under way to allow for noise reduction on new motors." (1985) } \\
\text { "The experimental compressor at Pierrelatte is launched. This high-strength compressor } \\
\text {. . . was developed as a feasibility study for the [French] Atomic Energy Agency." } \\
\text { (1971) }\end{array}$ \\
\hline
\end{tabular}


ing that Snecma (alone) "built" or "sold" engines was the norm. In all but four interviews, interviewees stated with no reference to GE that Snecma manufactured the CFM56 engine.

\section{PREEMPTIVE NEUTRALIZATION}

When not structurally omitting the past, Snecma's rhetorical history typically preemptively neutralized the foreign collaborations. This preemptive neutralization helped to dilute the memory of foreign presences at the company and created the conditions for subsequent forgetting. In doing so, Snecma was again upholding its national identity. The bulletins' treatment of Snecma's German engineers exemplifies such preemptive neutralization. The aforementioned limited references to the German presence in the internal bulletins were almost always coupled with the reinforcement of French patriotic claims. As an illustration, although it was the norm, at the time, to offer citizenship as part of a strategic transfer, not all Germans opted for citizenship (Bodemer \& Laugier, 1996). Oestrich's (1973) obituary in the Snecma bulletin ends by duly noting that he took French citizenship in 1948. The customary way to refer to Oestrich and the German engineers was to acknowledge their achievements and simultaneously to stress their acquired French patriotism. A typical internal bulletin, for instance, describes the arrival of the German engineers and immediately adds that the collaboration was undertaken "at the request and with the help" of the French government (Snecma, 1975: 3 ), thus stressing its patriotic context.

Other archival sources also capture the ongoing need to preemptively neutralize any perceived contradiction with Snecma's national identity by coupling the German past with patriotic cues. As an example, a 1996 history of Snecma by two former employees stresses that Oestrich "opted for French citizenship" (Bodemer \& Laugier, 1996). Likewise, another employee noted that Oestrich was a "naturalized" French citizen and was buried in France (Dodanthun, 1987: 39). In addition, a speech delivered at Snecma in 1995 by a German former colleague of Oestrich's who had by then returned to Germany illustrates such attempts at neutralizing perceived contradiction. After praising Snecma's achievements in "spearheading" European collaborations, he added: "My [German] colleagues and I are clearly emotionally involved with France; for proof, half of us stayed in this country [France]. The others, including myself, are always happy to come back here." (Von Gersdorff, 1996). This expression of patriotic allegiance conveys how Snecma members-even Germans-adopted the acceptable way to cast the German involvement in French aeronautics: by emphasizing their allegiance to France. Such preemptive neutralizing acts might seem singular and historically contingent (given Germany's former enemy status), but they also appear in the historical recollection of the GE collaboration.

The official justification for collaborating with GE was initially presented in pragmatic terms: international cooperation was deemed "nowadays necessary to launch new projects" in the civilian market (Snecma, 1972: 3). But the collaboration was also framed in the context of a broader national endeavor. In 1974, for instance, Snecma reminded its employees that the ten-ton engine (the CFM56) was a priority for the VIth National Development Plan drawn up by the French government (Snecma, 1974c: 2-3). Thus, the collaboration with GE was to some extent also branded a patriotic endeavor, echoing Snecma's earlier depiction of its reliance on German engineers. Although the bulletins described Snecma's agreement with GE as a way to "compete in collaboration and in close intelligence with our General Electric friends" (Snecma, 1981a: 8), the collaboration with GE still needed to be justified. The bulletin reminded its readers that the collaboration was "requested and supported by the French government," phrasing that deemphasized Snecma's active role in bringing about the collaboration (Snecma Informations. November 1979: 1). Overall, more than half of the 18 pages in the bulletins specifically discussing the GE collaboration provided readers with some reminder of the "patriotic" rationale for working with Americans (see Table 1). The rationales included collaborating at the request of the French government and/or to develop a national aeronautics capability.

The interview transcriptions and supplemental archives also contained instances of similar preemptive neutralization. An interviewee typically explained, "One should not forget that the Caravelle [a French plane] did not previously have a French engine. Here, we don't have a 100 percent French engine, but for the first time, at least with GE we aren't playing second fiddle. We are in the game." Another interviewee added, "While we might dream of doing everything on our own, the fact is that we cannot. Being with GE allows us to still be global leaders in engine manufacturing and that's what's important for Snecma." A different interviewee clarified, "We had to work with GE to maintain our lead. This was necessary for France." These quotes suggest that framing working with GE as in the national interest (rather than stressing an economic rationale) was the proper way to discuss the collaboration. 
Supplemental archives also tended to present and justify the GE collaboration with patriotic rationales. The joint manufacture of the CFM56 engine with GE needed to proceed in the "national interest" and for the "survival of the French aeronautics industry" (Snecma, 1973: 2). Even years into the collaboration, preemptively neutralizing GE's presence was often required. In the late 1980s, for instance, another Snecma employee justified working with GE to allow the French firm to become "the third engine manufacturer in the occidental world" (Dodanthun, 1987: 53). In 2000, a different Snecma employee also explained that the activities derived from collaborating with GE were a "consecration of Snecma's industrial capability" (Chilin, 2000a: 133), bolstering France's technological prowess. Put otherwise, across data sources, elements of the firm's national identity routinely appeared in the narratives directly discussing consequential foreign collaborations. Thus, the firm's collective memory preemptively neutralized contradictory elements of the past.

\section{DISCUSSION}

Our study documents the ongoing creation of a firm's unique rhetorical history by a varied cast of characters (the successive company bulletin editors) over nearly 50 years. Two distinct periods in Snecma's history characterized by crucial collaboration with foreign partners gave rise to the ongoing construction of this history. To sustain the national element of its identity, Snecma relied first on German expertise and later on collaboration with GE. Yet both foreign collaborations had the potential to create contradiction with the national underpinnings of Snecma's identity. Snecma's rhetorical history repeatedly omitted elements in the firm's past deemed "troubling" from its record (Horwitz, 1998; Wallace, 1996). Moreover, the rhetorical history continually attempted to preemptively neutralize these contradictory elements of the past with national identity cues. In other words, it called for invoking patriotism when potentially unpatriotic behavior was suspected. Combined, these strategies successfully upheld Snecma's collective memory, which partly allowed the firm to maintain its national identity.

Although we cannot entirely rule out the idea that Snecma's national identity did not change over time (Gioia \& Thomas, 1996; Glynn, 2000), it appeared to remain fairly enduring, and no data source suggests that it evolved, for instance, into a new interdependent identity. Thus, the study's findings shed light on the interplay of collective memory and organizational identity endurance. They show how a valued element of a firm's identity (here, its national identity) was sustained in the firm's collective memory (here, its internal bulletins) via repeated forgetting in its rhetorical history. The study also highlights the importance of forgetting, not only remembering, in collective memory processes. Repeated forgetting constitutes one link between collective memory and organizational identity endurance. Our findings provide an explanation of how an organizational identity can endure.

\section{Implications for Organizational Identity Research}

Our study first makes salient how organizational identities' apparent durability might prove more than merely "illusory" (Gioia et al., 2000: 64). Identities might be rendered enduring via collective memory, particularly through repeated forgetting and remembering. Our study therefore highlights both the collective and historical dimensions of identity work. Although identity work has been mainly theorized at the individual level, it also operates at the organizational level. Alongside previously noted collective identity management strategies (Dutton \& Dukerich, 1991; Gioia et al., 2010; Pratt \& Foreman, 2000; Ravasi \& Schultz, 2006), our study's findings make clear that the making of a collective memory is a form of collective identity work. Moreover, we already know that individual identity narratives often draw on remembered experiences (Ashforth et al., 2008: 345), yet these remembered experiences are also continuously collectively constructed. Thus, identity work entails not only looking individually from a present point in time backward (Brown \& Humphreys, 2002; Kimberly, 1987; Lawrence \& Suddaby, 2006) or forward (Corley \& Gioia, 2004; Gioia et al., 2000; Gioia \& Chittipeddi, 1991; Ibarra, 1999; Ravasi \& Schultz, 2006), but also engaging collectively over time in identity work that shapes an organization's memory.

Our study also emphasizes the place of forgetting in such collective memory constructions. Identity endurance might operate by discouraging some ways of experiencing the past while simultaneously encouraging alternate ways of experiencing the same past. The limited organizational identity literature on memory tends to focus on what is remembered, not on what is never acknowledged (Brown \& Humphreys, 2002; Chreim, 2005: 587; Kimberly \& Bouchikhi, 1995). Forgotten identities are generally considered merely because they were once remembered (Biggart, 1977; Corley \& Gioia, 2004; Fiol, 2002; Glynn \& Marquis, 2007; Zilber, 2002). This leaves systematic forgetting as an integral aspect of long-term identity construction 
largely unaccounted for. Yet remembering and forgetting are two sides of the same memory phenomenon. Like "voicing" and "self-editing" (Bernstein, 1964; Chafe, 1980), "sensegiving" and "sensehiding" (Vaara \& Monin, 2009) or "learning" and "unlearning" (Brunsson, 1998), they work concurrently. Shared beliefs about what elements of the past a community should remember to reinforce a collective identity are concomitant with shared beliefs about what elements of the past the community should not remember (Anderson \& Bjork, 1994; Anderson \& Spellman, 1995; Douglas, 1986; MacLeod \& Macrae, 2001; Misztal, 2003).

Deciding what to systematically forget or remember in a firm's history is an "ethics of memory" question (Margalit, 2002: 147): one involving conscious and/or unconscious decisions. Whetten noted that "we commit to our deepest memory the things we dare not forget" (2006: 224). A parallel phenomenon, we argue, might also be at play, one in which people relegate to forgetting the things they dare not remember. The repeated forgetting of "who we were not" in an organization's history might prove as central to the endurance of a given identity as remembering "who we are."

The above proposition forces conceptualization of forgetting as a collective identity enactment strategy rather than just an accidental cognitive failure of individuals. The particular attention to forgetting is warranted because studies of collective memory have shown that forgetting is crucial in maintaining the integrity of collective identities (Rivera, 2008). Societies and ethnic groups are often prone to forgetting events that represent a threat to their identity. In post-World War II Europe, for instance, the pressing need to reintegrate war-torn societies limited nations' willingness to expose their recent pasts and "favored" forgetting (Misztal, 2003: 148). In France and Italy in particular, collaboration with the Nazi regime was largely forgotten, replaced by an elaborate and carefully cultivated myth of resistance for the sake of reconciliation and national unity (Rousso, 1991), or what we might label "identity endurance." Similarly, organizational identity endurance might require organizational forgetting. An unanswered question is how much forgetting might be too much. For example, members might "disidentify" with an organization too prone to forgetting, underscoring the need for further studies of organizational members' experiences of forgotten identities.

\section{Implications for Collective Memory Research}

With respect to collective memory research and building on past work on organizational memory
(Brown \& Humphreys, 2002; Casey, 1997; Walsh, 1995; Walsh \& Ungson, 1991), our study first underscores the importance of treating organizations as mnemonic communities. We show that, like families and nations, organizations-especially those that endure a long time-build up extensive collective memories that are worth closely examining. Organizations "remember" their identity not only at discrete, eventful moments in time, but repeatedly, over extended periods. Such collective memories constitute rich narratives that organization members can rely on to make sense of their past, present, and future.

In addition, our study suggests that the rhetorical history constructed by a firm aims at influencing not only external agents (such as competitors and customers) but also internal organization members. This statement has important implications for collective memory research. Although our study emphasizes the ways in which collective memory sustains an organizational identity, a reverse directionality also likely operates. Thus, if collective memory can be conceptualized as a form of organizational identity work, organizational identity work might also be seen as constituting collective memories. Organizational identities could therefore be treated as "sites of memory," similar in essence to flags, anthems, or geographical places (Nora, 1996). Further research on the shifting nature of organizational identities might provide insights on the making of history. The shifting organizational identity of General Motors might, for instance, prove helpful in analyzing the firm's evolving collective memory.

Our case study also highlights the need to develop more nuanced understandings of forgetting as a form of collective memory. The different facets of remembering, including commemorations, ceremonies, photographs, nostalgia, traditions, and bodily practices, are well documented (Boym, 2001; Connerton, 1989; Hobsbawm \& Ranger, 1992; Mosse, 1975; Zelizer, 1998). By comparison, however, the various facets of forgetting are only beginning to be explored (Ciuk \& Kostera, 2010; Connerton, 2008). By identifying and analyzing key facets of forgetting (here, structural omission and preemptive neutralization), we hope to encourage more empirical research in this area. The analysis of routine organizational historical traces (such as internal bulletins, memoranda, and procedure manuals) can in that regard perhaps help identify other facets of forgetting. The task is likely to be complicated by the fact that rarity and scarcity tend to induce historical data survival (Boorstin, 1989: 8). As an example, it is often easier to access precious engraved manuscripts from the Middle Ages than widely 
used almanacs from the same period. Similarly, a signed original interfirm cooperation contract might be more easily located and accesses than routine organizational traces. Despite access complexities, a more systematic attention to such routine traces will probably yield insights into rich organizational histories. When studying organizations with identity contradictions, we speculate that analyses of routine traces will more likely showcase the backstage of identity work than analyses of more public data such as annual reports. Whereas public reports tend to exhibit the results of identity negotiations, routine traces likely capture the struggles and identity work needed to attain those results.

\section{Bridging Research Implications}

Many of the already outlined implications lie at the intersection of organizational identity and collective memory research, yet some additional bridging implications are worth emphasizing. Most significantly, our study's findings challenge assumptions on where identity and collective memory reside. Because we suggest that a locus of identity work can be collective memory (and vice versa), more attention needs to be paid to the historical dimension of identity work and the identity dimension of collective memory. For instance, to what extent is identity historically context dependent, and to what extent is history malleable, susceptible to change via identity dynamics? Moreover, if an organizational identity cannot only be captured in the present, how does one study it to account for its complexity? Also, if collective memory intersects with identity work, how does one account for the interplay?

Our findings also suggest that the collective identity of various communities can be intricately connected: an organization's identity may draw on elements of the historical identity of the institution in which it operates (e.g., a nation-state). Further research might examine the circumstances under which an organizational identity may interact with institutional identities, specifically, national ones (Chartier, 1985; Vallas, 1993: 70). As an example, "Frenchness" at Snecma built on, yet did not fully equate with, Frenchness in other settings. Our study therefore raises new questions about the coupling and decoupling of historical institutional and organizational identities.

In particular, an organization's identity can be more strongly associated with a nation-state than the nation-state's own identity. For instance, an organization could be more "American" than the United States. Whereas nation-states' identities of- ten prove complex, organizational identities tend to be more focused and easily controlled. Organizations (e.g., the Coca Cola Company) might therefore be able to develop "sharper" and "purer" national identities than nation-states. Organizational identity work might overlap in these and other instances with institutional work (Lawrence, Suddaby, \& Leca, 2009). Institutions such as nation-states can enable or disable organizational identities (Glynn, 2008). The identity work deployed in any organizational context can therefore echo, crystalize, or compete with other collective identities. Further inquiries into such interplays seem promising.

\section{Practical Implications}

Our findings have several important implications for practice. First, they suggest that sustaining an organizational identity requires more than managing valued identity attributes. Handling potential identity contradictions is also essential. When faced with such contradictions, managers might be inclined to ignore them; instead, proactively addressing them is central to identity endurance. The need for such action is often recognized in relation to external audiences (e.g., an external public relations firm might be hired to "fix" a brand's identity), but less often recognized in relation to internal ones. A second implication is to recognize the need to refocus managerial attention on a firm's past, not only its future. Although strategic planning and envisioning exercises are typically seen as part of a manager's job, the treatment of the past often fails to register as a critical task. Yet the ongoing crafting of a firm's rhetorical history facilitates the creation of a collective memory that, in turn, can sustain the firm's identity. Thus, a manager's ability to infuse meaning into work depends in part on her or his ability to help others remember and forget.

Our study also highlights the significant role routine organizational traces play in a firm's collective memory. A third practical implication is for managers not to overlook the generative nature of such traces. The production of internal bulletins might seem like a mundane task, one possibly even outsourced. What our study suggests, however, is that routine traces can significantly shape and capture a firm's identity. They cumulatively create and reflect what many managers aim to promote, namely, a shared sense of belonging among employees. The challenge for managers is double: first, to recognize the importance of what appears to be mundane and, second, to operate on a timeline that goes beyond their own promotion schedule. Managers 
might therefore need to expand their time horizons, since the making of a collective memory typically extends over a longer period than any given job rotation or even individual tenure at a firm.

\section{Limitations and Future Directions}

First, like other case-based research, this study was not designed to assess the frequency of occurrences of repeated forgetting in organizations. Instead, it aims to identify and analyze this form of organizational memory as it relates to organizational identity. Further studies might compare instances of organizational forgetting exhibited at different organizations and over time. Also, exploring what level of forgetting allows organizations to perform best in the long run could forge a link between organizational memory and performance. It is possible that a limited initial need for organizational identity work could confer long-term benefits, more or less in the same way that movie actors who are type-cast early on (as "action heroes," for example) have a higher probability in the long run of finding work than actors who play a wider range of roles (Zuckerman, Kim, Ukanwa, \& von Rittmann, 2003). Adding an organizational performance variable to historical analyses might thus prove productive. Also, identifying and analyzing instances and types of memory occurrences leading to decreased performance could suggest ways in which collective memory might backfire.

Second, we documented one of many possible intersections between organizational identity endurance and collective memory. Our focus is mainly on the projected official organizational identity - one that is integral to a firm's image and reputation (Dutton \& Dukerich, 1991; Fine, 2001; Fombrun, 1996). Yet an organization's identity can encompass additional aspects and be documented from different vantage points (Pratt, 2003); multiple “core" elements of an entity's identity may thus emerge (Corley et al., 2006: 91). The projected official organizational identity presented here likely coexists with other identities, such as the firm's "vernacular" identity (Bodnar, 1992). Similarly, a national identity is likely one of the many cores that an organization can embrace (Bartel, Blader, \& Wrzesniewski, 2007: 3). In addition, our analysis focuses on only one form of collective memory: a firm's official rhetorical history. Future researchers might want to longitudinally study multiple elements of an identity (e.g., official and vernacular ones) and examine how alternate facets of collective memory (e.g., traditions and industrial museums) might apply differently to various elements. Workplace jokes and songs might, for instance, prove more relevant to the endurance of vernacular identities than other facets of memory.

The main purpose of this case study was to generate new theoretical insights, yet our findings may apply to other contexts as well. As an example, comparable identity preservation attempts on the GE side might also exist. More broadly, at the international level, our findings might extend to joint ventures, international scientific collaborations, and cross-border acquisitions. Also, at the national level, our findings might apply, for instance, to local banks integrating into national banking groups or local funeral homes being consolidated into national chains. Given that social identities, including organizational ones, have been posited to arise from frictions (Fontdevila, Opazo, \& White, 2011: 185; White, 2008: 9), repeated forgetting in a firm's rhetorical history may be a more consequential phenomenon than the first few decades of organizational identity research would suggest. The continued historical examination of this phenomenon and other facets of collective memory might also provide novel keys to a better understanding of organizational identity work. Only by paying close attention to the collective and historical dynamics that sustain identities will the puzzle of identity endurance gradually be solved.

\section{REFERENCES}

Ackerman, M. S. 1998. Augmenting organizational memory: A field study of Answer Garden. ACM Transaction on Information Systems, 16: 203-224.

Ailon-Souday, G., \& Kunda, G. 2003. The local selves of global workers: The social construction of national identity in the face of organizational globalization. Organization Studies, 24: 1073-1096.

Albert, S., \& Whetten, D. 1985. Organizational identity. In L. L. Cummings \& B. M. Staw (Eds.), Research in organizational behavior, vol. 7: 263-295. Greenwich, CT: JAI Press.

Alvesson, M., \& Willmott, H. 2002. Identity regulation as organizational control: Producing the appropriate individual. Journal of Management Studies, 39: 619644.

Anand, V., Manz, C. C., \& Glick, W. H. 1998. An organizational memory approach to information management. Academy of Management Review, 23: 796809.

Anderson, B. 1991. Imagined communities: Reflections on the origins and spread of nationalism. London: Verso. 
Anderson, M. C., \& Bjork, R. A. 1994. Remembering can cause forgetting: Retrieval dynamics in long-term memory. Journal of Experimental Psychology: Learning, Memory \& Cognition, 20: 1063-1087.

Anderson, M. C., \& Spellman, B. A. 1995. On the status of inhibitory mechanisms in cognition: Memory retrieval as a model case. Psychological Review, 102: 68-100.

Angus, L. B. 1993. Masculinity and women teachers at Christian Brothers College. Organization Studies, 14: $235-260$.

Anteby, M. 2008. Moral gray zones: Side productions, identity, and regulation in an aeronautic plant. Princeton, NJ: Princeton University Press.

Appadurai, A. e. 1986. The social life of things: Commodities in cultural perspective. Cambridge, U.K.: Cambridge University Press.

Argote, L. 1999. Organizational learning: Creating, retaining, and transfer knowledge. Boston: Kluwer Academic.

Ashforth, B. E. 2001. Role transitions in organizational life: An identity-based perspective. Mahwah, NJ: Erlbaum.

Ashforth, B. E., Harrison, S. H., \& Corley, K. G. 2008. Identification in organizations: An examination of four fundamental questions. Journal of Management, 34: 325-374.

Audrieu, C. 1987. Des nationalisations disparates. In C. Audrieu, L. Le Van, \& A. Prost (Eds.), Les nationalisations de la Libération [The nationalizations of the Liberation]: 250-266. Paris: Presses de la Fondation Nationale des Sciences Politiques.

Bartel, C., Blader, S. L., \& Wrzesniewski, A. 2007. Identity and the modern organization. Mahwah, NJ: Erlbaum.

Bechky, B. 2003. Object lessons: Workplace artifacts as representations of occupational jurisdiction. American Journal of Sociology, 109: 720-752.

Bellah, R. N., Madsen, R., Sullivan, W. M., Swidler, A., \& Tipton, S. M. 1985. Habits of the heart: Individualism and commitment in American life. New York: Harper \& Row.

Benkhard, C. L. 2000. Learning and forgetting: The dynamics of aircraft production. American Economic Review, 90: 1034-1054.

Bernard, J.-P., \& Raffy, P. 1975. Le turboréacteur CFM56: Un progrès dans la réduction des bruits des moteurs [The turboreactor CFM56: Progress in reducing motor noise], technical note 75-33. CEDOCAR, Paris.

Bernstein, B. 1964. Elaborated and restricted codes: Their social origins and some consequences. American Anthropologist, 66(6): 55-69.
Biggart, N. W. 1977. The creative-destructive process of organizational change: The case of the post office. Administrative Science Quarterly, 22: 410-426.

Bodemer, A. 1986. De l'hélice à l'aviation à réaction (moteurs militaires] [From propellers to turbojet engines (military engines)]. Paper presented at the Colloque de l'Aéronautique à l'Espace, Paris.

Bodemer, A., \& Laugier, R. 1996. L'ATAR et tous les autres moteurs à réaction français [The ATAR and all other French engines]. Riquewihr, France: Editions J.D. Reber.

Bodnar, J. 1992. Remaking America: Public memory, commemoration, and patriotism in the twentieth century. Princeton, NJ: Princeton University Press.

Bohnekamp, D. 2002. Les ingénieurs allemands dans l'industrie française d'armement entre 1945 et 1950 [German engineers in the French armament industry between 1945 and 1950]. Revue d'Allemagne, 34: 29-44.

Bonnet, Y. 1996. Snecma de 1970 à nos jours [Snecma from 1970 to today]. Paper presented at the Moteurs d'Aviation: Colloque International, Centre d'Histoire de l'Aéronautique et de l'Espace, Paris.

Boorstin, D. J. 1989. Hidden history. New York: Vintage.

Boym, S. 2001. The future of nostalgia. New York: Basic Books.

Brown, A. D. 2006. A narrative approach to collective identities. Journal of Management Studies, 43: 731-753.

Brown, A. D., \& Humphreys, M. 2002. Nostalgia and the narrativization of identity: A Turkish case study. British Journal of Management, 13(2): 141-159.

Brunninge, O. 2009. Using history in organizations: How managers make purposeful reference to history in strategy processes. Journal of Organizational Change Management, 22: 8-26.

Brunsson, K. 1998. Non-learning organizations. Scandinavian Journal of Management, 14: 421-432.

Callon, M. 2009. Foreword. In G. Hecht (Ed.), The radiance of France: Nuclear power and national identity after World War II: xi-xxiii. Cambridge, MA: MIT Press.

Carlier, C. 1986. Introduction to the Colloque de I'Aéronautique à l'Espace [Introduction to the Colloquium "From Aeronautics to Space"]. Paper presented at the Institut d'Histoire des Conflits Contemporains, Paris.

Carlier, C. 1997a. Chronologie aérospatiale, politique, militaire 1945-1995 [Aerospace, political, and military history 1945-1955]. Paris: Economica.

Carlier, C. 1997b. Le “Groupe O” (1945-1960) [“Group O” (1945-1960)]. Institut Historique Allemand, 
Paris. http://www.stratisc.org/ihcc_GROUPO.html, accessed April 9, 2009.

Casey, A. 1997. Collective memory in organizations. In J. Walsh \& A. Huff (Eds.), Advances in strategic management, vol. 14: 111-146. Greenwich, CT: JAI Press.

Chafe, W. L. 1980. The pear stories: Cognitive, cultural, and linguistic aspects of narrative. Norwood, NJ: Ablex.

Chartier, R. 1985. Text, symbols, and frenchness. Journal of Modern History, 57: 682-695.

Chilin, R. 2000a. Bataille pour le civil, le conflit de 1969 [The fight for the civilian market: The conflict of 1969]. In R. Chilin \& R. Mullier (Eds.), Pages d'histoire syndicale: La CFTC-CFDT SNECMA-Villaroche, 1947-1980: 109-142. Paris: L'Harmattan.

Chilin, R. 2000b. Une section syndicale face à la réalité [A union section faces reality]. In R. Chilin \& R. Mullier (Eds.), Pages d'histoire syndicale: La CFTC-CFDT SNECMA-Villaroche, 1947-1980: 17102. Paris: L'Harmattan.

Chilin, R., \& Mullié, R. 2000. Pages d'histoire syndicale: La CFTC-CFDT SNECMA-Villaroche, 1947-1980 [Pages of union history: The CFTC-CFDT SnecmaVillaroche, 1947-1980]. Paris: L'Harmattan.

Chreim, S. 2005. The continuity-change duality in narrative texts of organizational identity. Journal of Management Studies, 42: 567-593.

Ciuk, S., \& Kostera, M. 2010. Drinking from the waters of Lethe: A tale of organizational oblivion. Management Learning, 41(2): 187-204.

Clark, S. M., Gioia, D. A., Ketchen, D. J. J., \& Thomas, J. B. 2010. Transitional identity as facilitator of identity change during a merger. Administrative Science Quarterly, 55: 397-438.

Clegg, S. R., Rhodes, C., \& Kornberger, M. 2007. Desperately seeking legitimacy: Organizational identity and emerging industries. Organization Studies, 28: 495513.

Comité pour l'Histoire de l'Aéronautique. 2003. Un demi-siècle d'aéronautique en France [A halfcentury of aeronautics in France]. Paris: Centre des Hautes Etudes de l'Armement, Département de l'Histoire de l'Armement.

Connerton, P. 1989. How societies remember. Cambrige, U.K.: Cambridge University Press.

Connerton, P. 2008. Seven types of forgetting. Memory Studies, 1: 59-71.

Corley, K. G., \& Gioia, D. A. 2004. Identity ambiguity and change in the wake of a corporate spin-off. Administrative Science Quarterly, 49: 173-208.
Corley, K. G., Harquail, C. V., Pratt, M. G., Glynn, M. A., Fiol, C. M., \& Hatch, M. J. 2006. Guiding organizational identity through aged adolescence. Journal of Management Inquiry, 15: 85-99.

Creed, W. E. D., DeJordy, R., \& Lok, J. 2010. Being the change: Resolving institutional contradiction through identity work. Academy of Management Journal, 53: 1336-1364.

Creed, W. E. D., \& Seo, M.-G. 2002. Institutional contradictions, praxis, and institutional change: A dialectical perspective. Academy of Management Review, 27: 222-247.

Czarniawska, B., \& Wolff, R. 1998. Constructing new identities in established organization fields: Young universities in old Europe. International Studies of Management \& Organization, 28(3): 32-56.

Danel, R., \& Cuny, J. 1978. L'aviation Française de bombardement et de renseignement (1918/1940) [The French bombing and intelligence aviation (1918/ 1940)]. Paris: Editions Larivière.

Daniel, C., Arzoglou, E., \& Lamont, M. 2011. European workers: Meaning-making beings. In Research in the sociology of work: Comparing European workers, vol. 22: 287-312. Bingley, U.K.: Emerald Group.

de Holan, P. M., \& Phillips, N. 2004. Remembrance of things past? The dynamics of organizational forgetting. Management Science, 50: 1603-1613.

Djelic, M.-L. 1998. Exporting the American model: The post-war transformation of European business. Oxford, U.K.: Oxford University Press.

Dodanthun, G. 1987. Gnome, Gnome et Rhône, Snecma: Des moteurs rotatifs aux turboréacteurs [Gnome, Gnome et Rhône, Snecma: From rotating engines to turbojet engines]. Paris: Snecma.

Douglas, M. 1986. How institutions think. Syracuse, NY: Syracuse University Press.

Dutton, J. E., \& Dukerich, J. M. 1991. Keeping the eye on the mirror: The role of image and identity in organizational adaptation. Academy of Management Journal, 34: 517-554.

Dutton, J. E., Dukerich, J. M., \& Harquail, C. V. 1994. Organizational image and member identification. Administrative Science Quarterly, 39: 239-263.

Elsbach, K. D., \& Kramer, R. M. 1996. Members' responses to organizational identity threats: Encountering and countering the business week rankings. Administrative Science Quarterly, 41: 442-476.

Ericson, M. 2006. Exploring the future exploiting the past. Journal of Management History, 12(2): 121-136.

Feldman, M. S., \& Pentland, B. T. 2003. Reconceptualizing organizational routines as a source of flexibility and change. Administrative Science Quarterly, 48: $94-118$. 
Feldman, R. M., \& Feldman, S. P. 2006. What links the chain: An essay on organizational remembering as practice. Organization, 13: 861-887.

Fine, G. A. 2001. Difficult reputations: Collective memory of the evil, inept, and controversial. Chicago: University of Chicago Press.

Fiol, C. M. 2002. Capitalizing on paradox: The role of language in transforming organizational identities. Organization Science, 13: 653-666.

Fombrun, C. J. 1996. Reputation: Realizing value from the corporate image. Cambridge, MA: Harvard Business School Press.

Fontdevila, J., Opazo, M. P., \& White, H. C. 2011. Order at the edge of chaos: Meanings from netdom switchings across functional systems. Sociological Theory, 29: 178-198.

Foster, W. M., Suddaby, R., Minkus, A., \& Wiebe, E. 2011. History as social memory assets: The example of Tim Hortons. Management $\&$ Organizational History, 6: 101-120.

Fox-Wolfgramm, S. J., Boal, K. B., \& Hunt, J. G. J. 1998. Organizational adaptation to institutional change: A comparative study of first-order change in prospector and defender banks. Administrative Science Quarterly, 43: 87-126.

Fridenson, P., \& Lecuir, J. 1969. L'organisation de la cooperation aérienne Franco-Britannique (1935-Mai 1940) [The structure of Franco-British aerial cooperation between 1935 and May 1940]. Revue d'Histoire de la Seconde Guerre Mondiale, 73(January): $43-74$.

Gagliardi, P. 1986. The creation and change of organizational cultures: A conceptual framework. Organization Studies, 7: 117-134.

Gioia, D. A., \& Chittipeddi, K. 1991. Sensemaking and sensegiving in strategic change initiation. Strategic Management Journal, 12: 433-448.

Gioia, D. A., Corley, K. G., \& Fabbri, T. 2002. Revising the past (while thinking in the future perfect tense). Journal of Organizational Change Management, 15: 622-634.

Gioia, D. A., Price, K. N., Hamilton, A. L., \& Thomas, J. B. 2010. Forging an identity: An insider-outsider study of processes involved in the formation of organizational identity. Administrative Science Quarterly, 55: 1-46.

Gioia, D. A., Schultz, M., \& Corley, K. G. 2000. Organizational identity, image, and adaptive instability. Academy of Management Review, 25: 63-81.

Gioia, D. A., \& Thomas, J. B. 1996. Identity, image, and issue interpretation: Sensemaking during strategic change in academia. Administrative Science Quarterly, 41: 370-403.
Glynn, M. A. 1997. Commentary: Collective memory as fact and artifact: Cultural and political elements of memory in organizations. In J. Walsh \& A. Huff (Eds.), Advances in strategic management, vol. 14: 147-154. Greenwich, CT: JAI Press.

Glynn, M. A. 2000. When cymbals become symbols: Conflict over organizational identity within a symphony orchestra. Organization Science, 11: 285-298.

Glynn, M. A. 2008. Beyond constraint: How institutions enable identities. In R. Greenwood, C. Oliver, K. Sahlin-Andersson, \& R. Suddaby (Eds.), Handbook of organizational institutionalism: 413-430. Thousand Oaks, CA: Sage.

Glynn, M. A., \& Marquis, C. 2007. Legitimating identities: How institutional logics motivate organizational name choices. In C. A. Bartel, S. Blader, \& A. Wrzesniewski (Eds.), Identity and the modern organization: 17-34. Mahwah, NJ: Erlbaum.

Greenberg, E. S., Grunberg, L., Moore, S., \& Sikora, P. B. 2010. Turbulence: Boeing and the state of American workers and managers. New Haven, CT: Yale University Press.

Halbwachs, M. 1992. On collective memory. Chicago: University of Chicago Press.

Hamdouch, A. 1989. L'etat d'influence: Nationalisations et privatisations en France [State influence: Nationalization and privatization in France]. Paris: Presses du Centre National de la Recherche Scientifique.

Hatch, M. J. 2005. Identity: Organizational. In N. Nicholson, P. Audia, \& M. Pillutla (Eds.), The Blackwell encyclopedia of management (2nd ed.): 160-161. London: Basil Blackwell.

Hecht, G. 1998. The radiance of France: Nuclear power and national identity after World War I. Cambridge, MA: MIT Press.

Hedden, C. 2004. International collaboration: Challenges are technical, human and political. Aviation Week and Space Technology, 161(December 13): S1-S4.

Hobsbawm, E., \& Ranger, T. 1992. The invention of traditions. Cambridge, U.K.: Cambridge University Press.

Holt, D. B. 2006. Jack Daniel's America: Iconic brands as ideological parasites and proselytizers. Journal of Consumer Culture, 6: 355-377.

Horwitz, T. 1998. Confederates in the attic: Dispatches from the unfinished Civil War. New York: Pantheon.

Huber, G. P. 1991. Organizational learning: The contributing processes and literatures. Organization Science, 2: 88-115. 
Hunt, L. 1991. Secret agenda: The United States government, Nazi scientists, and project paperclip, 1945-1990. New York: St. Martin’s Press.

Ibarra, H. 1999. Provisional selves: Experimenting with image and identity in professional adaptation. $\boldsymbol{A d}$ ministrative Science Quarterly, 44: 764-791.

Jenkins, R. 2008. Social identity. New York: Routledge.

Journal Officiel de la République Française. 1945. Ordre présidentiel 45-1086: Transfert à l'etat des actions de la société anonyme des moteurs, Gnome et Rhône [Presidential order 45-1086: Transfer to the state of the shares of the incorporated engine company, Gnome et Rhône], May 30.

Kimberly, J. R. 1987. The study of organizations: Toward a biographical perspective. In J. W. Lorsch (Ed.), Handbook of organizational behavior: 223-237. Englewood Cliffs, NJ: Prentice Hall.

Kimberly, J. R., \& Bouchikhi, A. 1995. The dynamics of organizational development and change: How the past shapes the present and constrains the future. Organization Science, 6: 9-18.

Kuisel, R. F. 1997. Seducing the French: The dilemma of Americanization. Berkeley: University of California Press.

Lachaume, P. 1986. De l'hélice à l'aviation à réaction (moteurs civils), [From propellers to turbojet engines (civilian engines)]. Paper presented at the Colloque de l'Aéronautique à l'Espace, Paris.

Lamouche, R. 1999. Histoire du centre aéronautique de Melun-Villaroche [History of the aeronautics center of Melun-Villaroche]. Hericy, France: Editions du Puits Fleuri.

Langlay, A. 1999. Strategies for theorizing from process data. Academy of Management Review, 24: 691710 .

Lawrence, T. B., Suddaby, R., \& Leca, B. 2009. Introduction: Theorizing and studying institutional work. In T. B. Lawrence, R. Suddaby, \& B. Leca (Eds.), Institutional work: Actors and agency in institutional studies of organizations: 1-27. Cambridge, U.K.: Cambridge University Press.

Lawrence, T. B., \& Suddaby, R. 2006. Institutions and institutional work In S. Clegg, C. Hardy, T. B. Lawrence, \& W. R. Nord (Eds.), Handbook of organization studies: 215-254. London: Sage.

MacLeod, M. D., \& Macrae, C. N. 2001. Gone but not forgotten: The transient nature of retrieval-induced forgetting. Psychological Science, 12(2): 148-152.

Margalit, A. 2002. The ethics of memory. Cambridge, MA: Harvard University Press.

Misztal, B. 2003. Theories of social remembering. Maidenhead, U.K.: Open University Press.
Moorman, C., \& Miner, A. S. 1998. Organizational improvisation and organizational memory. Academy of Management Review, 23: 698-723.

Mosse, G. L. 1975. The nationalization of the masses: Political symbolism and mass movement in Germany from the Napoleonic Wars through the Third Reich. New York: Fertig.

Nora, P. 1996. Realms of memory. New York: Columbia University Press.

Olick, J. K. 2003. States of memory: Continuities, conflicts, and transformations in national retrospection. Durham, NC: Duke University Press.

Olick, J. K. 2007. The politics of regret: On collective memory and historical responsibility. London: Routledge.

Olick, J. K., \& Levy, D. 1997. Collective memory and cultural constraint: Holocaust myth and rationality in German politics. American Sociological Review, 62: 921-936.

Olick, J. K., \& Robbins, J. 1998. Social memory studies: From "collective memory" to the historical sociology of mnemonic practices. In J. Hagan \& K. Cook (Eds.), Annual review of sociology, vol. 24: 105-140. Palo Alto, CA: Annual Reviews.

Pratt, M. G. 2003. Disentangling collective identities. In J. T. Polzer, E. Mannix, \& M. A. Neale (Eds.), Identity issues in groups: Research on managing groups and teams, vol. 5: 161-188. Stamford, CT: JAI Press.

Pratt, M. G. 2009. For the lack of a boilerplate: Tips on writing up (and reviewing) qualitative research. Academy of Management Journal, 52: 856-861.

Pratt, M. G., \& Foreman, P. O. 2000. Classifying managerial responses to multiple organizational identities. Academy of Management Review, 25: 18-42.

Pratt, M. G., \& Rafaeli, A. 1997. Organizational dress as a symbol of multilayered social identities. Academy of Management Journal, 40: 862-898.

Pratt, M. G., Rockmann, K. W., \& Kaufmann, J. B. 2006. Constructing professional identity: The role of work and identity learning cycles in the customization of identity among medical residents. Academy of Management Journal, 49: 235-262.

Rao, H. 1998. Caveat emptor: The construction of nonprofit consumer watchdog organizations. American Journal of Sociology, 103: 912-961.

Ravasi, D., \& Schultz, M. 2006. Responding to organizational identity threats: Exploring the role of organizational culture. Academy of Management Journal, 493: 433-458.

Rivera, L. 2008. Managing 'spoiled' national identity: War, tourism, and memory in Croatia. American Sociological Review, 73: 613-635. 
Rousso, H. 1991. The Vichy syndrome: History and memory in France since 1944. Cambridge, MA: Harvard University Press.

Rowlinson, M., Booth, C., Clark, P., Delahaye, A., \& Procter, S. 2010. Social remembering and organizational memory. Organization Studies, 31: 69-87.

Rozenblatt, P. 1989. Compromis d'entreprise, médiation syndicale, et dynamique sociale [Business compromise, union mediation, and the social dynamic]. Paris: GIP Mutations Industrielles, CNRS.

Safran. 2006. Document de reférénce pour l'autorité des marchés financiers [Reference document for the financial markets regulating authority]. Paris: Safran.

Salaman, G. 1978. Towards a sociology of organizational structure. Sociological Review, 26: 519-554.

Schneiberg, M., \& Clemens, E. 2006. The typical tools for the job: Research strategies in institutional analysis. Sociological Theory, 24: 195-227.

Schwartz, B. 2000. Abraham Lincoln and the forge of national memory. Chicago: Chicago University Press.

Selznick, P. 1957. Leadership in administration. New York: Harper \& Row.

Smith, V. 1990. Managing in the corporate interest: Control and resistance in an American bank. Berkeley: University of California Press.

Snecma. 1953. Snecma Informations [Snecma News], October, 1: 8-9.

Snecma. 1956. Rapport annuel 1955 [Annual report 1955]. Paris: Comité Central d’Entreprise.

Snecma. 1959. La crise de l'aéronautique Française: Ses conséquences dramatiques à la Snecma [The crisis of French aeronautics: Dramatic consequences for Snecma]. Paris: Comité Central d'Entreprise.

Snecma. 1960. Bulletin d'information du personnel Snecma [Snecma employee newletter]. Paris: Comité Central d'Entreprise.

Snecma. 1970. Activités [Activities]. Bulletin d'information du Comité Local d'Etablissement Snecma Villaroche. Paris: Comité Central d'Entreprise.

Snecma. 1971. Snecma Informations. December supplement.

Snecma. 1972. Snecma Informations. November, 189.

Snecma. 1973. Activités. Bulletin d'information du Comité Local d'Etablissement Snecma Villaroche [News bulletin of Snecma Villaroche's local labor committee]. Paris: Comité Central d'Entreprise.

Snecma. 1974a. Snecma Informations. March, 203.

Snecma. 1974b. Snecma Informations. June, 206.
Snecma. 1974c. Snecma Informations. July-August, 207.

Snecma. 1975. Snecma Informations. December, 221.

Snecma. 1979. Snecma Informations. November, 258.

Snecma. 1981a. Snecma Informations. June, 271.

Snecma. 1981b. Snecma Informations. SeptemberOctober, 272.

Snecma. 1990. Snecma Informations. February, 317.

Snecma. 1999. Trait d'union, Bulletin d'Information Snecma Villaroche [Hyphen, Snecma Villaroche's News Bulletin]. December 19: 1.

Snecma. 2004. Document de base pour l'autorité des Marchés Financiers [Base document for the financial markets regulating authority]: I-04-I072. Paris.

Snecma. 2006. Rapport d'Activité [Annual report].

Snow, D. A., \& Leon, A. 1987. Identity work among the homeless: The verbal construction and avowal of personal identities. American Journal of Sociology, 92: 1336-1371.

Steele, C. M. 1988. The psychology of self-affirmation: Sustaining the integrity of the self. Advances in Experimental Social Psychology, 21: 261-302.

Strauss, A. L. 1987. Qualitative analysis for scientists. Cambridge, U.K.: Cambridge University Press.

Suddaby, R., Foster, W., \& Quinn-Trank, C. 2010. Rhetorical history as a source of competitive advantage. In J. A. C. Baum \& J. Lampel (Eds.), Advances in strategic management: The globalization of strategy research, vol. 27: 147-174. Bingley, U.K.: Emerald Group.

Tripsas, M. 2009. Technology, identity, and inertia through the lens of the "Digital Photography Company." Organization Science, 20: 441-460.

Tsoukas, H., \& Chia, R. 2002. On organizational becoming: Rethinking organizational change. Organization Science, 13: 567-582.

United States General Accounting Office. 1994. European aeronautics industry. Strong government presence in industry structure and research and development support. Washington, DC: GAO.

Vaara, E., \& Monin, P. 2009. A recursive perspective on discursive legitimation and organizational action in mergers and acquisitions. Organization Science, 21: 3-22.

Vallas, S. P. 1993. Power in the workplace: The politics of production at AT\&T. Albany: State University of New York Press.

Van Maanen, J. 1998. Identity work: Notes on the personal identity of police officers. Paper presented at the annual meeting of the Academy of Management, San Diego. 
Ventresca, M. J., \& Mohr, J. 2002. Archival methods in organization analysis. In J. A. C. Baum (Ed.), Companion to organizations: 805-828. New York: Blackwell.

Vivier, T. 1997. La politique aéronautique militaire de la France: Janvier 1933-Septembre 1939 [The politics of French military aeronautics: January 1933September 1939]. Paris: Editions L’Harmattan.

Von Gersdorff, C. 1996. Commémoration des anciens du “Groupe O": 100 ans de moteurs d'aviation, 50 ans de SNECMA [Commemoration of the former members of the "O Group": Aviation engines' 100 years, Snecma's 50 years]. Paris: Snecma.

Wagner-Pacifici, R., \& Schwartz, B. 1991. The Vietnam Veterans Memorial: Commemorating a difficult past. American Journal of Sociology, 97: 376-420.

Wallace, M. 1996. Mickey Mouse history and other essays on American history. Philadelphia: Temple University Press.

Walsh, J. P. 1995. Mangerial and organizational cognition: Notes from a trip down memory lane. Organization Science, 6: 280-321.

Walsh, J. P., \& Ungson, G. R. 1991. Organizational memory. Academy of Management Review, 16: 57-91.

Watson, T. J. 2008. Managing identity: Identity work, personal predicaments and structural circumstances. Organization, 15: 121-143.

Weber, K., Heinze, K. L., \& deSoucey, M. 2008. Forage for thought: Mobilizing codes in the movement for grass-fed meat and dairy products. Administrative Science Quarterly, 53: 529-567.

Weick, K. E. 1969. The social psychology of organizing. Reading, MA: Addison-Wesley.

Whetten, D. 2006. Albert and Whetten revisited: Strengthening the concept of organizational identity. Journal of Management Inquiry, 15: 219-234.

White, H. C. 2008. Identity and control: How social formations emerge. Princeton, NJ: Princeton University Press.
Zelizer, B. 1998. Remembering to forget: Holocaust memory through the camera's eye. Chicago: University of Chicago Press.

Zerubavel, E. 1996. Social memories: Steps to a sociology of the past. Qualitative Sociology, 19: 283-299.

Zilber, T. B. 2002. Institutionalization as an interplay between actions, meanings, and actors: The case of a rape crisis center in Israel. Academy of Management Journal, 45: 234-254.

Zilber, T. B. 2009. Institutional maintenance as narrative acts. In T. B. Lawrence, R. Suddaby, \& B. Leca (Eds.), Institutional work: Actors and agency in institutional studies of organizations: 205-235. Cambridge, U.K.: Cambridge University Press.

Zuckerman, E. W., Kim, T.-Y., Ukanwa, K., \& von Rittmann, J. 2003. Robust identities or nonentities? Typecasting in the feature-film labor market. American Journal of Sociology, 108: 1018-1074.

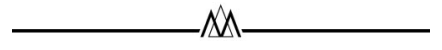

Michel Anteby (manteby@hbs.edu) is an associate professor in the organizational behavior unit at Harvard Business School. He holds a joint Ph.D. in management and sociology from New York University and the École des Hautes Études en Sciences Sociales in Paris. His research examines organizational and occupational cultures, particularly their interplay with meaning and morals.

Virág Molnár (molnarv@newschool.edu) is an assistant professor of sociology at the New School for Social Research. She received a Ph.D. in sociology from Princeton University. Her main research foci include collective memory, politics of the urban public sphere, and social change, especially the relationship between state formation and transformations of the built environment. 
Copyright of Academy of Management Journal is the property of Academy of Management and its content may not be copied or emailed to multiple sites or posted to a listserv without the copyright holder's express written permission. However, users may print, download, or email articles for individual use. 